WSRC-TR-2000-00304

SRT-RPP-2000-00005

Revision 0

\title{
Studies of Ion Exchange Resin Integrity under Flowsheet Extremes: Part II
}

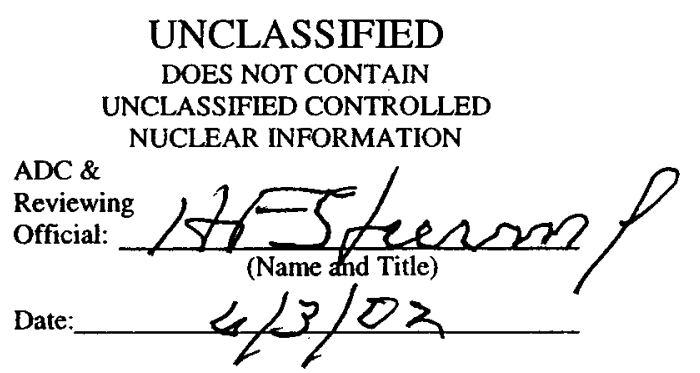

Westinghouse Savannah River Company

Savannah River Site

Aiken, SC 29808

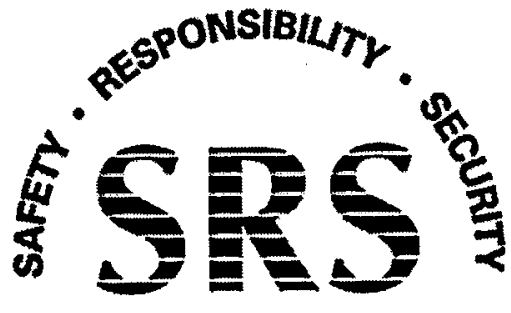

Prepared for the U.S. Department of Energy under Contract No. DE-AC09-96SR18500

SAVANNAH RIVER SITE 
This document was prepared in conjunction with work accomplished under Contract No. DE-AC09-96SR18500 with the U. S. Department of Energy.

\section{DISCLAIMER}

This report was prepared as an account of work sponsored by an agency of the United States Government. Neither the United States Government nor any agency thereof, nor any of their employees, makes any warranty, express or implied, or assumes any legal liability or responsibility for the accuracy, completeness, or usefulness of any information, apparatus, product or process disclosed, or represents that its use would not infringe privately owned rights. Reference herein to any specific commercial product, process or service by trade name, trademark, manufacturer, or otherwise does not necessarily constitute or imply its endorsement, recommendation, or favoring by the United States Government or any agency thereof. The views and opinions of authors expressed herein do not necessarily state or reflect those of the United States Government or any agency thereof.

This report has been reproduced directly from the best available copy.

Available for sale to the public, in paper, from: U.S. Department of Commerce, National Technical Information Service, 5285 Port Royal Road, Springfield, VA 22161, phone: (800) 553-6847, fax: (703) 605-6900

email: orders@ntis.fedworld.gov

online ordering: http://www.ntis.gov/help/index.asp

Available electronically at http://www.osti.gov/bridge

Available for a processing fee to U.S. Department of Energy and its contractors, in paper, from: U.S. Department of Energy, Office of Scientific and Technical Information, P.O. Box 62, Oak Ridge, TN 37831-0062,

phone: (865)576-8401,

fax: (865)576-5728

email: $\underline{\text { reports@ adonis.osti.gov }}$ 
WSRC-TR-2000-00304

SRT-RPP-2000-00005

\title{
KEYWORDS:
}

Hanford River Protection Project

Nitric Acid

Stability

\section{Studies of Ion Exchange Resin Integrity under Flowsheet Extremes: Part II}

SAVANNAH RIVER TECHNOLOGY CENTER

\author{
W.J. Crooks III \\ C.A. Nash \\ D.J. McCabe \\ H.H. Saito
}

May 31, 2002

Westinghouse Savannah River Company

Savannah River Site

Aiken, SC 29808

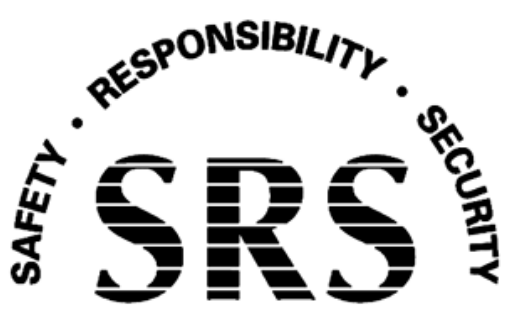

Prepared for the U.S. Department of Energy under Contract No. DE-AC09-96SR18500 
DOCUMENT: $\quad$ WSRC-TR-2000-00304 (SRT-RPP-2000-00005), Revision 0 TITLE: $\quad$ Studies of Ion Exchange Resin Integrity under Flowsheet Extremes: Part II

\section{APPROVALS}

Willuaif Coshe III Date: $5 / 31 / 02$ W. J. Crooks, III (ATS/SRTC)

Chaule A, C.A. Nash (WTT/SRTC)
Date:

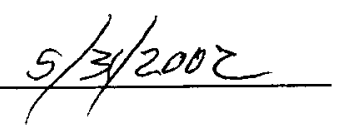

Chanler A. Narh son D. Vi Mclale D.J. McCabe (WTT/SRTC)
Date: $s(y) / 2002$

Willuing Crooks III for H.H. Saito Date: $5 / 31 / 02$ H.H. Saito (WTT/SRTC)

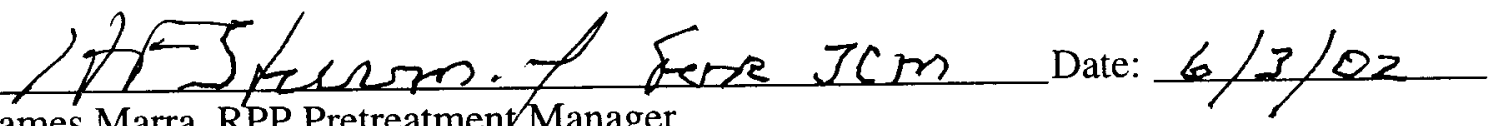
James Marra, RPP Pretreatmen Manager

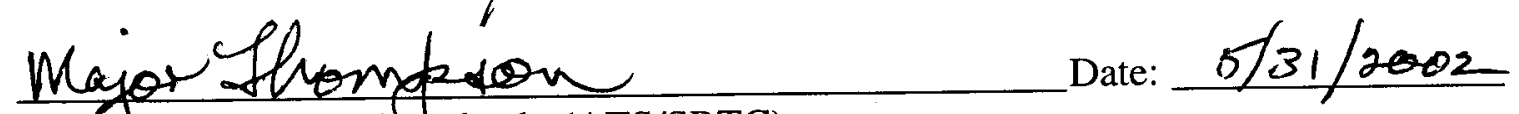

MajofThompson, Design check (ATS/SRTC)

Document previously transmitted as BNF-003-98-0312, Rev. 0 
WSRC-TR-2000-00304, Rev. 0

SRT-RPP-2000-00005

Rev. 0

\section{Table of Contents}

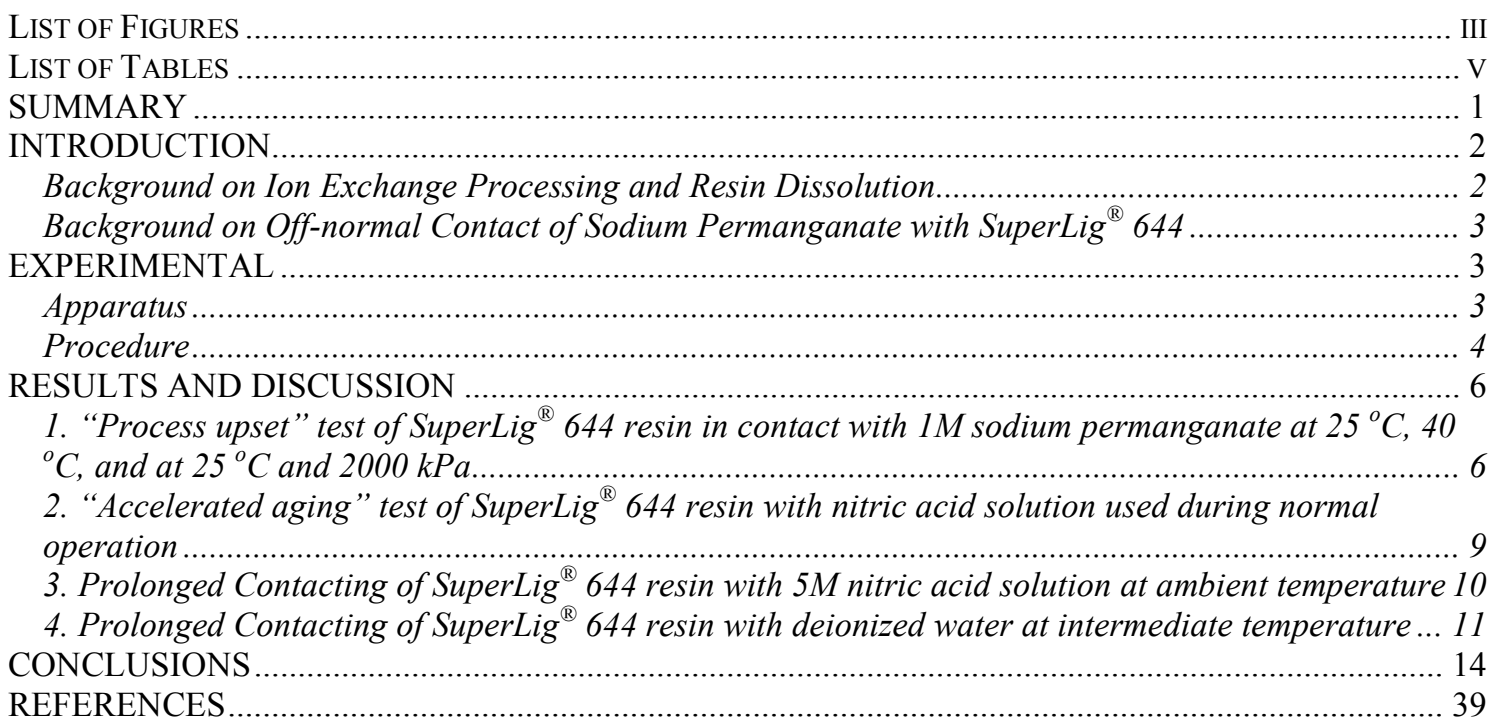


WSRC-TR-2000-00304, Rev. 0

SRT-RPP-2000-00005

Rev. 0

\section{List of Figures}

Figure 1. PHOTOGRAPH OF THE PARR BOMB OF THE RSST .....................................................5

FIGURE 2. SKETCH OF THE RSST .........................................................................6

FIGURE 3. SUPERLIG® 644 RESIN AND 1 MOLAR SODIUM PERMANGANATE.......................... 16

FIGURE 4. SUPERLIG ${ }^{\circledR} 644$ RESIN AND 1 MOLAR SODIUM PERMANGANATE ........................... 16

FIGURE 5. SUPERLIG ${ }^{\circledR} 644$ RESIN AND 1 MOLAR SODIUM PERMANGANATE ............................ 17

FIGURE 6. SUPERLIG ${ }^{\circledR} 644$ RESIN AND 1 MOLAR SODIUM PERMANGANATE ........................... 17

FIGURE 7. SUPERLIG ${ }^{\circledR} 644$ RESIN AND WATER ................................................................. 18

FIGURE 8. SUPERLIG ${ }^{\circledR} 644$ RESIN AND WATER ............................................................. 18

FIGURE 9. SUPERLIG ${ }^{\circledR} 644$ RESIN AND WATER ............................................................. 19

FIGURE 10. SUPERLIG ${ }^{\circledR} 644$ RESIN AND WATER .................................................................. 19

FIGURE 11. SUPERLIG ${ }^{\circledR} 644$ RESIN AND 1 MOLAR SODIUM PERMANGANATE .......................... 20

FIGURE 12. SUPERLIG ${ }^{\circledR} 644$ RESIN AND 1 MOLAR SODIUM PERMANGANATE ......................... 20

FIGURE 13. SUPERLIG ${ }^{\circledR} 644$ RESIN AND 1 MOLAR SODIUM PERMANGANATE .........................21

FIGURE 14. SUPERLIG ${ }^{\circledR} 644$ RESIN AND 1 MOLAR SODIUM PERMANGANATE ........................ 21

FIGURE 15. SUPERLIG ${ }^{\circledR} 644$ RESIN AND 0.5 MOLAR NITRIC ACID .......................................... 22

FIGURE 16. SUPERLIG ${ }^{\circledR} 644$ RESIN AND 0.5 MOLAR NITRIC ACID .......................................... 22

FIGURE 17. SUPERLIG ${ }^{\circledR} 644$ RESIN AND 0.5 MOLAR NITRIC ACID ........................................... 23

FIGURE 18. SUPERLIG ${ }^{\circledR} 644$ RESIN AND 0.5 MOLAR NITRIC ACID ............................................ 23

FIGURE 19. SUPERLIG ${ }^{\circledR} 644$ RESIN AND 5 MOLAR NITRIC ACID ..............................................2 24

FIGURE 20. SUPERLIG ${ }^{\circledR} 644$ RESIN AND 5 MOLAR NITRIC ACID ............................................ 24

FIGURE 21. SUPERLIG ${ }^{\circledR} 644$ RESIN AND 5 MOLAR NITRIC ACID ........................................... 25

FIGURE 22. SUPERLIG ${ }^{\circledR} 644$ RESIN AND 5 MOLAR NITRIC ACID ............................................. 25

FigURE 23. CAUSTIC NEUTRALIZATION OF "SUPERLIG ${ }^{\mathbb{B}} 644$ SOLUTION" ............................. 26

FiguRE 24. CAUSTIC NEUTRALIZATION OF "SUPERLIG ${ }^{\circledR} 644$ SOLUTION" ..............................26

FiguRE 25. CAUSTIC NEUTRALIZATION OF "SUPERLIG ${ }^{\circledR} 644$ SOLUTION" ............................. 27

FiguRE 26. CAUSTIC NEUTRALIZATION OF "SUPERLiG ${ }^{\circledR} 644$ SOLUTION" ............................ 27

FIGURE 27. SUPERLIG ${ }^{\circledR} 644$ RESIN AND WATER...............................................................28

FIGURE 28. SUPERLIG ${ }^{\circledR} 644$ RESIN AND WATER................................................................28

Figure 29. CAUSTIC NEUTRALIZATION OF "SUPERLiG ${ }^{\circledR} 644$ SOLUTION" ............................ 29

Figure 30. CAUSTIC NEUTRALIZATION OF "SUPERLIG ${ }^{\mathbb{B}} 644$ SOLUTION" ..............................29

Figure 31. ICMS OF the PRoduct From Test 8: "PARTIAL" DisSOlution OF SL644 IN 5M NITRIC ACID AT $25{ }^{\circ} \mathrm{C}$ FOR 21 DAYS.........................................................................30

Figure 32. ICMS OF THE PRODUCT FROM TEST 8: “COMPLETE" DisSOLUTION OF SL644 IN 5M NITRIC ACID AT $90{ }^{\circ} \mathrm{C}$ FOR 8 HOURS................................................................31

Figure 33. ICMS OF THE PRODUCT FROM TEST 9: PARTIAL DISSOLUTION OF SL644 IN DiSTILLED WATER AT $60{ }^{\circ} \mathrm{C}$ FOR 7 DAYS .......................................................................32

Figure 34. DSC OF Test 7: RESIN $+0.5 \mathrm{M} \mathrm{HNO}_{3}$ AT $90{ }^{\circ} \mathrm{C}$ FOR 24 HOURS $\rightarrow$ LIQUid RESIDUE..................................................................................................................... 33

Figure 35. DSC OF TEST 7: RESIN $+0.5 \mathrm{M} \mathrm{HNO}_{3}$ AT $90{ }^{\circ} \mathrm{C}$ FOR 24 HOURS $\rightarrow$ SOlid

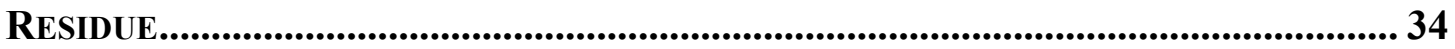

Figure 36. DSC OF TEST 8: RESIN + 5M HNO 3 AT AMBIENT TEMPERATURE FOR 21 DAYS $\rightarrow$ LIQUID RESIDUE 
WSRC-TR-2000-00304, Rev. 0

SRT-RPP-2000-00005

Rev. 0

Figure 37. DSC OF TEST 8: RESIN + 5M HNO 3 AT AMBIENT TEMPERATURE FOR 21 DAYS $\rightarrow$ SOLID RESIDUE. 36

Figure 38. DSC OF TeSt 9: RESIN $+\mathrm{H}_{2} \mathrm{O}$ AT $60^{\circ} \mathrm{C}$ FOR 7 DAYS $\rightarrow$ LiQuid ReSidue .... 37

Figure 39. DSC OF TEST 9: RESIN $+\mathrm{H}_{2} \mathrm{O}$ AT $60{ }^{\circ} \mathrm{C}$ FOR 7 DAYS $\rightarrow$ Solid ReSIDUe ...... 38 
WSRC-TR-2000-00304, Rev. 0

SRT-RPP-2000-00005

Rev. 0

\section{List of Tables}

TABLE 1. SUMMARY OF REACTANTS FOR RESIN STABILITY TESTS IN RSST ........................... 4

Table 2. Net Pressure Changes Associated with Sodium Permanganate Addition

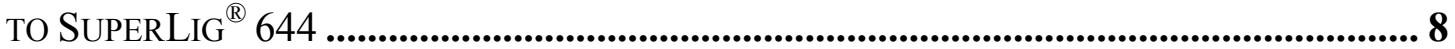

TABLE 3. ANALYSIS OF GASES AND LIQUID RESIDUE USING VOA, SVOA AND SVOC .... 12

TABLE 4. ANALYSIS OF SOLID AND LIQUID RESIDUE DSC ……………............................... 13

TABLE 5. CAUSTIC NEUTRALIZATION OF SUPERLIG ${ }^{\circledR} 644$ SOLUTION .................................... 13 
WSRC-TR-2000-00304, Rev. 0

SRT-RPP-2000-00005

Rev. 0

\section{SUMMARY}

This task addressed four items related to SuperLig ${ }^{\circledR} 644$ ion exchange resin stability under nominal to extreme conditions: ${ }^{1}$

A process upset analysis of resin in contact with 1 molar sodium permanganate at 25 and $40{ }^{\circ} \mathrm{C}$ identified runaway reaction behavior that was characterized by acute selfheating and sample ejection with only condensable gas (e.g. steam) evolution. An analogous test of the resin-permanganate reaction under $2000 \mathrm{kPa}$ prevented sample ejection, displayed a temporary pressure rise, but showed no net evolution of noncondensable gases. Follow-on work done before this report was finalized suppressed sample ejection by testing a range of initial elevated pressures. ${ }^{2}$

A simulation of the accelerated aging of resin during normal dilute acid $(0.5 \mathrm{M})$ regeneration operations identified no measurable reactivity.

The behavior of resin in 5 molar nitric acid at ambient temperatures was characterized by a slow, steady evolution of noncondensable gases $\left(\mathrm{NO}_{\mathrm{x}}\right.$ and $\left.\mathrm{CO}_{2}\right)$, and dissolved $80 \%$ of the resin after 21 days. The neutralization of this acidic "SuperLig ${ }^{\circledR} 644$ resin solution" with sodium hydroxide was characterized as a rapid exothermic reaction without foaming, bubbling, or precipitation.

Resin exposure to water at $60{ }^{\circ} \mathrm{C}$ showed no measurable gas evolution, and dissolved $55 \%$ of the resin mass after 7 days. The cause for the loss in resin mass could not be definitively determined. It might have been due largely to the presence of a substantial amount of potassium bicarbonate contained within the as-received resin supplied by the vendor. Substantial dissolution of the resin in water was not anticipated and further work is needed to determine what is occurring.

Work to follow that reported here shall address the potassium bicarbonate content of the as-received resin by pretreating the resin. The presence of approximately $50 \mathrm{wt} \%$ potassium bicarbonate in the resin was a recent discovery. ${ }^{3}$ The bicarbonate affected batch distribution and mass loss/dissolution work up to the point that it was discovered.

Differential scanning calorimetry (DSC) analysis of solid and liquid residues showed small heat flow, evidence that the potential reactivity of these resin-nitric acid reaction products is small to negligible. Volatile organic analysis (VOA) did not identify any reactive degradation products. Semi-volatile organic compound analysis (SVOC) of liquid residues did not identify typical low molecular weight resin degradation products. Liquid reaction products have been analyzed by liquid chromatography-mass spectrometry (LC-MS). In summary, this work characterized the reactivity SuperLig ${ }^{\circledR} 644$ ion exchange resin under various conditions as part of the validation of waste treatment technologies to be employed by the Hanford River Protection Project-Waste Treatment Plant (RPP-WTP). The quantified impact of the results from these tests on facility design will be addressed in a separate document by the design authority. 
WSRC-TR-2000-00304, Rev. 0

SRT-RPP-2000-00005

Rev. 0

\section{INTRODUCTION}

Incidents involving undesirable self-accelerated exothermic reactions between organic resins and nitric acid solutions have been well documented. ${ }^{3,4,5,6,7,8}$ The work reported here is intended to address safety concerns during normal and off-normal operations during the use of SuperLig ${ }^{\circledR} 644$ ion exchange resin to separate cesium from low activity waste streams. This report covers the thermal behavior characterization of resin under various conditions, and an evaluation of the potential energy release from the solid, liquid and gaseous reaction products. This work is a sequel to the resin-nitric acid stability testing at high temperatures. ${ }^{3}$ The objective of this work is to characterize the reactivity of SuperLig ${ }^{\circledR} 644$ and identify a margin of safety for plant process operations. These results are intended to be used by the design authority, along with additional testing that has been performed at SRTC and elsewhere, to determine the impact on facility design safety. The design authority will develop the bounding facility conditions (e.g., safe concentration of permanganate solution, pressure relief capacity, etc.).

\section{Background on Ion Exchange Processing and Resin Dissolution}

The RPP-WTP process for separating cesium and technetium from low-activity waste solutions uses SuperLig ${ }^{\circledR} 644$ and SuperLig ${ }^{\circledR} 639$ resins, respectively. RPP-WTP plans to elute the SuperLig ${ }^{\circledR} 644$ resin with $0.5 \mathrm{M}$ nitric acid and concentrate the eluate at $50-60$ ${ }^{\circ} \mathrm{C}$ under sufficient vacuum to cause boiling and concentrate the solution to $80 \%$ total salts saturation and $\sim 5 \mathrm{M}$ nitric acid. SuperLig ${ }^{\circledR} 644$ resin particles could potentially exit from the ion exchange column during elution due to failure of the resin retention mechanism (Johnson wedge-wire screen) or attrition of resin particles. Therefore, resin could be boiled with the eluate solution, leading to potential adverse reactions (e.g. energy release).

The initial study of resin-nitric acid mixtures evaluated the energetics and decomposition products from contacting SuperLig ${ }^{\circledR} 644$ resin particles at $90{ }^{\circ} \mathrm{C}$ in $5 \mathrm{M}$ nitric acid to simulate off-normal operating temperatures during plant evaporation and concentration processes. These results show that SuperLig ${ }^{\circledR} 644$ will likely completely dissolve in the $5 \mathrm{M}$ nitric acid solution with evolution of nitrous oxide and carbon dioxide, but not hydrogen gas. Differential scanning calorimetry of the evaporated liquid and the solids residues from the incomplete digestion of resin and $5 \mathrm{M}$ nitric acid showed no exotherms. As a control blank, an additional test of resin in water showed that about $50 \%$ of the resin dissolved after contacting for 24 hours at temperatures of 90 to $100{ }^{\circ} \mathrm{C}$.

These initial results suggest that it may be possible to safely dissolve SuperLig ${ }^{\circledR} 644$ in $5 \mathrm{M}$ nitric acid (or water at elevated temperatures). Resin dissolution at ambient temperature is desirable to avoid additional process equipment and controls. This may provide a means to dispose of the spent resin by feeding it to the LAW melter as opposed to radioactive solid waste. To evaluate the possibility of resin dissolution, the reaction of SuperLig ${ }^{\circledR} 644$ in nitric acid at ambient temperature and in water at $60{ }^{\circ} \mathrm{C}$ needs to be studied. For each reaction, the energetics, pressure rate increase, temperature, composition of gases evolved, and extent of dissolution were determined and documented in order to evaluate potential safety hazards. 
WSRC-TR-2000-00304, Rev. 0

SRT-RPP-2000-00005

Rev. 0

In addition, the RPP-WTP process for eluting cesium from SuperLig ${ }^{\circledR} 644$ involves contact with $0.5 \mathrm{M}$ nitric acid solution for prolonged periods at nominally $25^{\circ} \mathrm{C}$. The stability of the resin in contact with the dilute elution acid at off-normal temperatures needs to be evaluated. The energetics, pressure rate increase, temperature, and composition of gases evolved were determined and documented to evaluate potential safety hazards and identify operational limits.

The behavior of SuperLig ${ }^{\circledR} 644$ resin under conditions of $0.5 \mathrm{M}$ and $5 \mathrm{M}$ nitric acid under conditions of room temperature for periods of up to one month were already addressed by IBC Technologies. ${ }^{8}$ Resin exposed to $0.5 \mathrm{M}$ nitric acid was found to not dissolve much and to still perform after one month of exposure. IBC also confirmed that $5 \mathrm{M}$ and $12.2 \mathrm{M}$ nitric acid dissolved most to all of the resin in just a few minutes.

\section{Background on Off-normal Contact of Sodium Permanganate with SuperLig ${ }^{\circledR} 644$}

The RPP-WTP process for separating $\mathrm{Sr}^{90}$ and transuranic elements for Envelope C solutions uses sodium hydroxide, strontium nitrate, and sodium permanganate solutions. A hazard review has postulated a scenario in which sodium permanganate solution could be inadvertently transferred into the feed vessel for the cesium ion exchange column, and then into columns containing SuperLig ${ }^{\circledR} 644$ resin. To evaluate this potential safety hazard, the pressure rate increase, temperature rate increase, and composition of gases evolved were determined and documented.

This work addresses four items related to SuperLig ${ }^{\circledR} 644$ resin stability: (1) process upset evaluation of resin in contact with 1 molar sodium permanganate at 25 and $40{ }^{\circ} \mathrm{C}$,

(2) accelerated aging with nitric acid solution used during normal regeneration operations, (3) prolonged contacting of SuperLig ${ }^{\circledR} 644$ resin with 5 molar nitric acid at ambient temperature, and (4) prolonged contacting of SuperLig ${ }^{\circledR} 644$ resin with deionized water at $60 \pm 5{ }^{\circ} \mathrm{C}$.

This task fulfills all the requests as defined in Task Technical Plan BNF-003-98-0225. Quality Assurance requirements were applied to this work as described in BNF-003-980225, Studies of Ion Exchange Resin Integrity under Flowsheet Extremes: Part II, W. Crooks, C. Nash, D. McCabe, H. Saito.

\section{EXPERIMENTAL}

\section{Apparatus}

The Reactive System Screening Tool (RSST) was used to characterize the thermal effects of the reactions between SuperLig ${ }^{\circledR} 644$ organic resin and process chemicals. The RSST calorimeter is traditionally used for the efficient screening of runaway reactions as a function of temperature, and also serves as a reactor vessel. The RSST is a nearly adiabatic calorimeter that heats an open, well-insulated 14-mL test cell within a sealed $350-\mathrm{mL}$ Parr bomb (Figures 1 and 2). The test cell mixture is stirred and heated at a nearly 
WSRC-TR-2000-00304, Rev. 0

SRT-RPP-2000-00005

Rev. 0

constant rate and the Parr bomb and test cell are monitored for temperature and pressure, respectively. All tests utilized SuperLig ${ }^{\circledR} 644$ (batch \# 981020MB48-563), as received.

\section{Procedure}

Accelerated aging tests, the permanganate reaction tests, and the resin digestion/dissolution tests were performed using the RSST. The general procedure used for conducting RSST tests is described below:

1. SuperLig ${ }^{\circledR} 644$ resin and a process solvent (nitric acid or water) was added to the test cell. However, sodium permanganate was added as described below.

2. The test cell was loaded into the Parr bomb, sealed, and the mixture was stirred and heated at a programmed rate. Alternately, because of the vigorous reactivity of $1 \mathrm{M}$ sodium permanganate reactions with SuperLig ${ }^{\circledR} 644$ resin at ambient temperature, the sodium permanganate solution is added via an extension tube to the dry resin loaded in the test cell within a sealed Parr bomb. The initial composition of the reaction mixture for all RSST tests in this work is described in Table 1. Tests 1-6 were designed to evaluate process upset due to resin in contact with 1 molar sodium permanganate. Test 7 was designed to simulate the effect of accelerated aging of resin in contact with the dilute nitric acid solution used during normal column regeneration operations. Tests 8 and 9 were designed to evaluate the dissolution of resin in either nitric acid or water.

Table 1. Summary of Reactants for Resin Stability Tests in RSST

\begin{tabular}{|c|c|c|c|c|c|c|c|c|}
\hline $\begin{array}{c}\text { Test } \\
\text { No. }\end{array}$ & $\begin{array}{c}\text { Record } \\
\text { Reference }\end{array}$ & $\begin{array}{c}\text { Initial Temp. } \\
{ }^{\circ} \mathrm{C}\end{array}$ & $\begin{array}{c}\text { Resin } \\
\mathrm{g}\end{array}$ & $\begin{array}{c}1 \mathrm{M} \mathrm{NaMnO}_{4} \\
\mathrm{~g}\end{array}$ & $\begin{array}{c}5 \mathrm{M} \mathrm{HNO}_{3} \\
\mathrm{~g}\end{array}$ & $\begin{array}{c}\text { Water } \\
\mathrm{g}\end{array}$ & $0.5 \mathrm{M} \mathrm{HNO}_{3}$ & $\begin{array}{c}\text { Initial Press. } \\
\mathrm{psig}\end{array}$ \\
\hline 1 & WJC-IV-025 & ambient & 2.51 & 7.93 & & & & 0 \\
\hline 2 & WJC-IV-027 & ambient & 2.51 & 7.93 & & & & 0 \\
\hline 3 & WJC-IV-033 & ambient & 2.50 & 7.92 & & & & 0 \\
\hline 4 & WJC-IV-035 & 40 & 2.51 & 7.93 & & & & 0 \\
\hline 5 & WJC-IV-109 & ambient & 2.52 & & & 8 & & 290 \\
\hline 6 & WJC-IV-111 & ambient & 2.52 & 8 & & & & 291 \\
\hline 7 & WJC-IV-009 & ambient & 2.50 & & & & 7.98 & 0 \\
\hline 8 & WJC-IV-021 & ambient & 0.40 & & 11.58 & & & 0 \\
\hline 9 & WJC-IV-045 & ambient & 0.40 & & & 10.00 & & 0 \\
\hline
\end{tabular}

3. The test cell mixture and the Parr bomb were monitored for temperature and pressure, respectively.

4. The pressure-temperature data were processed to generate plots of temperature vs. time, pressure vs. time, self-heating rate vs. temperature, rate of pressure change vs. temperature, and pressure vs. temperature.

5. The Analytical Development Section (ADS) analyzed sample chemistry per quality assurance requirements as well as tracking samples within the LIMS system. ADS analyzed liquid samples by SVOC and gaseous samples by VOA Halocarbon $(5 \mathrm{~mL}$ purge/trap) and VOA Halocarbon (direct gas loop). These organic analysis methods are consistent with EPA SW-846 methods, although the laboratory is not certified by 
the South Carolina Department of Health and Environmental Control for NPDES discharge compliance monitoring.

6. The Materials Technology Section (MTS) provided differential scanning calorimetry (DSC) analyses.

7. The Savannah River Ecology Lab performed Ion Cyclotron Mass Spectrometry (ICMS) of selected samples of resin mixtures in an effort to identify volatile and/or potentially energetic compounds. Samples were neutralized to about $\mathrm{pH} 2$ to 3 . The neutralized samples were then loaded onto a C-18 SPE column, eluted with methanol, diluted 1:1 with water, and $50 \mu \mathrm{L}$ of acetic acid was added. Samples were not separated into components by chromatography. Chemical ionization (CI) was used to introduce the sample into the ICMS. CI is a "soft" ionization method that generally will not cause fragmentation of molecules, and therefore, tends to produce parent molecular ions plus one proton, the $(\mathrm{M}+1)^{+}$peak. The spectra in this report were measured at low resolution $(\sim 0.02 \mathrm{~m} / \mathrm{z})$. Since samples were not separated into pure components by liquid chromatography, each spectrum contains the $(\mathrm{M}+1)^{+}$peak of each component, in addition to some fragmentation products. The SREL laboratory is not certified by the South Carolina Department of Health and Environmental Control for NPDES discharge compliance monitoring.

Figure 1. Photograph of the PARr Bomb of the RSST

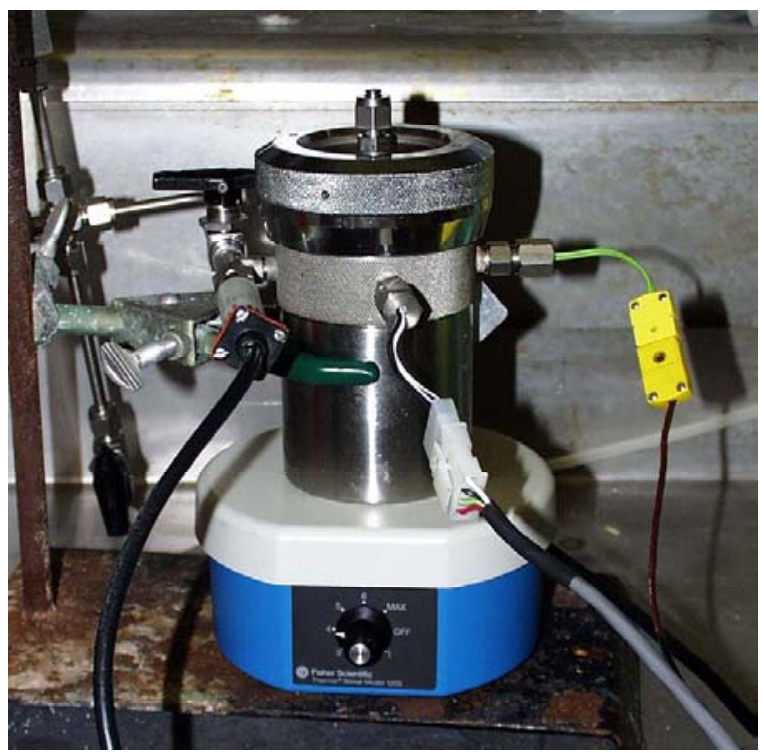


WSRC-TR-2000-00304, Rev. 0

SRT-RPP-2000-00005

Rev. 0

FiguRE 2. SKETCH OF THE RSST

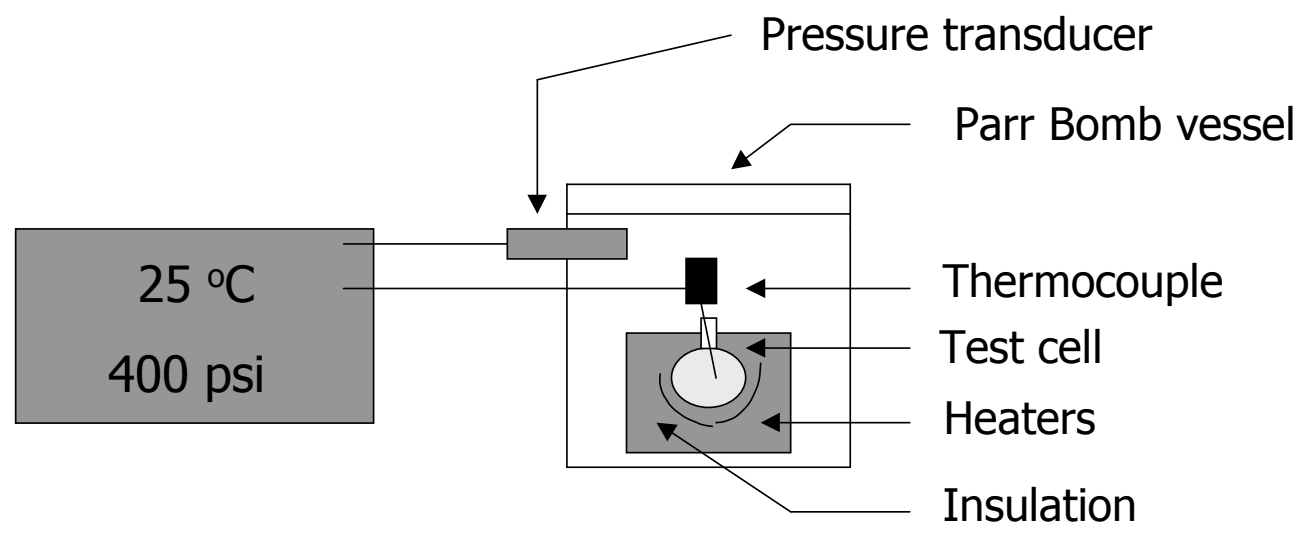

\section{Computer Parr bomb}

\section{RESULTS AND DISCUSSION}

\section{1. "Process upset" test of SuperLig ${ }^{\circledR} 644$ resin in contact with $1 M$ sodium permanganate at $25^{\circ} \mathrm{C}, 40{ }^{\circ} \mathrm{C}$, and at $25{ }^{\circ} \mathrm{C}$ and $2000 \mathrm{kPa}$}

Sodium permanganate is a powerful oxidizer that is expected to damage organic ion exchange resins. The purpose of this work was to characterize the reaction that will occur as a result of the accidental addition of sodium permanganate solution to the SuperLig ${ }^{\circledR} 644$ ion exchange column. To simulate resin packed in a column, the liquid:solid ratio was 3:1 (mass:mass). Resin was mixed with a solution of 1 molar sodium permanganate in the RSST at a specified temperature and pressure. Significant self-heating was observed although no heat was applied. The reactivity of the system was characterized by monitoring the temperature and pressure changes. Some of the samples were analyzed for gaseous products but none were identifiable.

\section{Scoping Test A: Reactivity assessment}

This test was performed in accord with the National Fire Protection Agency (NFPA) guidelines for working with potentially energetic compounds, as approved by the DOE Explosives Safety Committee. ${ }^{9,10}$ As suggested by the NPFA guidelines, the reactivity scoping test was performed in a chemical hood with less that $50 \mathrm{mg}$ of material, and personal protective equipment included leather gloves and a face shield. In addition, a Plexiglas ${ }^{\mathrm{TM}}$ barrier was in place between the test reaction and personnel. SuperLig ${ }^{\mathbb{B}} 644$ resin $(39.7 \mathrm{mg})$ was placed on a watchglass. A drop of 1 molar sodium permanganate was added, and no evidence of reaction was observed. No bubbling or foaming was observed. After 5 minutes, 5 additional drops were added, and a few small bubbles slowly formed and burst. These small bubbles could be the liberation of trapped air (lower solubility) due to self-heating from the exothermic reaction. The purple sodium permanganate turned 
WSRC-TR-2000-00304, Rev. 0

SRT-RPP-2000-00005

Rev. 0

brown upon addition. Although little to no gas is generated, the resin appeared to degrade and partially dissolve, forming a brown $\mathrm{MnO}_{2}$-resin slurry. No RSST test was performed.

\section{Scoping Test B: Scale-up reactivity at $25^{\circ} \mathrm{C}$.}

Based on the intensity of the reactivity scoping test, a mass scale-up test was performed in a test cell. Since this test simulates resin packed in a column, the target liquid:solid ratio was about 3:1. The RSST test cell was loaded with SuperLig ${ }^{\circledR} 644$ resin (2.501 grams). To the test cell was added 1 molar sodium permanganate ( 4.5 grams). In less than two seconds, the reaction mixture bubbled (probably generating steam), and was gently ejected from the test cell. The reaction mixture remaining in the test cell was $80{ }^{\circ} \mathrm{C}$ and cooling. The test cell was quickly placed in the Parr bomb and quickly sealed but no pressure generation was observed. Gas analysis by VOA showed only a trace of carbon dioxide. The resulting mixture was a brown slurry. No purple color remained, qualitative evidence that the permanganate ions were completely consumed in the reaction. This scoping test showed that a rapid addition of $\mathrm{NaMnO}_{4}$ to SuperLig ${ }^{\circledR} 644$ resin at atmospheric pressure leads to ejection of the reaction mixture from the test cell, although the reaction was complete before the system could be sealed, prohibiting measurement of gas evolution.

\section{Scale-up reactivity tests in a sealed $\mathrm{RSST}$ at ambient and $40{ }^{\circ} \mathrm{C}$.}

Tests 1-3. Based on the minimal intensity of the preceding scoping test, gram-scale tests were performed in a sealed RSST. Using the target liquid:solid ratio of about 3:1, the RSST test cell was charged with a SuperLig ${ }^{\circledR} 644$ resin and loaded into the RSST. Before the RSST test was started, the 1 molar sodium permanganate solution was added to the test cell by injecting the solution through an extension tube. The RSST reaction profiles shown in Figures 3-6 characterize the runaway reactions. Note that all pressures reported are gauge rather than absolute. All three tests showed rapid temperature and pressure excursions upon addition of sodium permanganate. Maximum self-heating rates were on the order of 500 to $1000{ }^{\circ} \mathrm{C} / \mathrm{min}$. The flattened portion of the self-heating profile is evidence of vapor saturation (i.e. boiling). Two minutes after addition, the temperature and pressure decrease, evidence that the sodium permanganate has been completely consumed.

Gas analyses from Test 1 (1-gas) and Test 2 (2-gas) are shown in the Results section.

Test 4. For the test starting at $40{ }^{\circ} \mathrm{C}$, the dry resin and permanganate solution were each pre-equilibrated in a water bath at temperature prior to being mixed. These results, which are included in Figures 3-6, started at a higher initial temperature but had similar reaction profiles to the tests starting at ambient temperature with one exception. The maximum pressure was much lower for the $40{ }^{\circ} \mathrm{C}$ test. One explanation is that initial reaction rate was higher at $40{ }^{\circ} \mathrm{C}$ (i.e. rate doubles with $10{ }^{\circ} \mathrm{C}$ increase). A more rapid reaction could result in ejection of sample before the reaction is complete. This result is consistent with the unusually charred condition of the test cell at the completion of Test 4. 
WSRC-TR-2000-00304, Rev. 0

SRT-RPP-2000-00005

Rev. 0

If a noncondensable gas is evolved during the permanganate tests, then a net pressure rise should be observed. The observed pressure rise is the sum of the pressure due to the charge of the liquid into the closed system and any pressure generated from the reaction. An initial test (performed in triplicate) showed that the addition of $10 \mathrm{~mL}$ of water to the sealed RSST results in a pressure rise of $3 \mathrm{kPa} \pm 0.1$ (theoretical pressure rise is $\sim 3 \mathrm{kPa}$ gauge). Therefore, to correct for pressure associated with addition of the 10-mL liquid reactant, the net pressure change, $\Delta \mathrm{P}_{\text {net }}$, is given by the following equation:

$$
\Delta \mathrm{P}_{\text {net }}=\Delta \mathrm{P}_{\exp }-3 \mathrm{kPa}
$$

Table 2 shows the net pressure changes associated with the addition of sodium permanganate to resin, after subtracting the pressure change associated with the addition of $10 \mathrm{~mL}$ of liquid. The negligible to small net pressure changes in tests $1-4$ suggest that noncondensable gases (e.g. carbon dioxide) are not evolved during the reaction.

Table 2. Net Pressure Changes Associated with Sodium Permanganate Addition to SuperLig ${ }^{\circledR} 644$

\begin{tabular}{|c|c|c|c|}
\hline $\begin{array}{c}\text { Test } \\
\text { No. }\end{array}$ & $\begin{array}{c}\text { Record } \\
\text { Name }\end{array}$ & $\begin{array}{c}\text { Initial Temp. } \\
{ }^{\circ} \mathrm{C}\end{array}$ & $\begin{array}{c}\Delta \mathrm{P}_{\text {net }} \\
\mathrm{Pa}\end{array}$ \\
\hline 1 & WJC-IV-025 & ambient & 0 \\
\hline 2 & WJC-IV-027 & ambient & 1 \\
\hline 3 & WJC-IV-033 & ambient & 5 \\
\hline 4 & WJC-IV-035 & 40 & 0 \\
\hline
\end{tabular}

Test 5. To suppress sample ejection during sodium permanganate addition to resin, highpressure tests were performed. Dry resin was placed in the Parr bomb and pressurized to about $2000 \mathrm{kPa}$ with nitrogen. Note that all pressures reported are gauge rather than absolute. A high-pressure syringe was loaded with the water, and attached to the extension tube of the RSST. After the pressure reading stabilized, the water was charged into the test cell using a $690 \mathrm{kPa}$ overpressure (about $2690 \mathrm{kPa}$ ) on the high-pressure syringe. No reaction was expected but pressure changes associated with the addition of liquid to the sealed Parr bomb, and temperature changes associating with the mixing process were evaluated in this control run. The RSST reaction profiles are shown in Figures 7-10. Pressure and temperature changes before the system was stabilized to begin the test are included for completeness. The addition of water causes an immediate $0.5^{\circ} \mathrm{C}$ temperature rise (Figure 7) and $50 \mathrm{kPa}$ pressure rise (Figure 8). After the system came to thermal equilibrium, the net pressure rise was $35 \mathrm{kPa}$. Therefore, an increase in system pressure of about $35 \mathrm{kPa}$ is associated with the addition of the liquid to the sealed system.

Test 6. The addition of sodium permanganate solution to resin was characterized by a rapid temperature and pressure excursion upon addition of sodium permanganate (Figures 11-14). However, the maximum self-heating rate of $45^{\circ} \mathrm{C} / \mathrm{min}$ occurred at $30{ }^{\circ} \mathrm{C}$. In contrast to Tests 1-3 in which vapor saturation was observed, the high pressure suppressed 
WSRC-TR-2000-00304, Rev. 0

SRT-RPP-2000-00005

Rev. 0

the solvent vaporization, and no sample was ejected from the test cell. The net pressure rise was $30 \mathrm{kPa}$. This value is smaller than the net pressure rise from the water test $(35 \mathrm{kPa})$. The pressure rate plot in Figure 14 shows an initial pressure rate spike associated with addition of sodium permanganate, and a small pressure rate increase from 40 to $50{ }^{\circ} \mathrm{C}$ which is likely associated with the vaporization of solvent. This evidence suggests that noncondensable gases are not generated from the reaction of sodium permanganate and SuperLig ${ }^{\circledR} 644$ resin.

Ion Cyclotron Mass Spectrometry (ICMS) was performed on the brown slurry residue from Test 6 . The mass spectrum contained a large distribution of peaks with a wide range of mass $/$ charge $(\mathrm{m} / \mathrm{z})$ ratio. This large distribution of compounds is consistent with the general degradation of the organic resin, however, no peak predominated and no peaks could be identified. The spectrum is not included in this report.

\section{2. "Accelerated aging" test of SuperLig ${ }^{\circledR} 644$ resin with nitric acid solution used during normal operation}

Resin in 0.5 molar nitric acid was heated in the RSST. The reactivity of the system was characterized by monitoring temperature and pressure changes. Solid, liquid and gaseous degradation products were analyzed.

Scoping test. In preparation for the RSST, the addition of $1 \mathrm{~mL}$ of 0.5 molar nitric acid to dry SuperLig ${ }^{\circledR} 644$ resin resulted in a immediate foaming and fizzing, causing a resin-acid mixture to be ejected from the test cell. The ejected material was a pale-green/brown color, with a white foamy head. The run was aborted.

Test 7. An alternate preparation was devised to prevent ejection of sample during the test cell loading. To the 2.5 grams of dry resin at room temperature was added 7.19 grams of water followed incremental addition of 50 to $100 \mu \mathrm{L}$ aliquots of $5 \mathrm{M}$ nitric acid (total 790 $\mu \mathrm{L}$ ) over a 30 minute period. The RSST was then sealed, and the mixture was run with an imposed self-heating rate of $0.25{ }^{\circ} \mathrm{C} / \mathrm{min}$ to $90{ }^{\circ} \mathrm{C}$, and held for 24 hours. The RSST reaction profiles are shown in Figures 15-18. No exotherm was observed. The only evidence of reaction was the net pressure increase was $5 \mathrm{kPa}$ gauge(ambient temperature). The gas was not analyzed. Dried solids and evaporated and dried liquid samples were analyzed by DSC (Table 4, Figures 34 and 35)). The analysis of the liquid and solid samples identified no reactive compounds.

The resin residue $(1.2431 \mathrm{~g})$ and residue recovered in the rinses $(0.0181 \mathrm{~g})$ was combined to give $1.2612 \mathrm{~g}$ of solid mass recovered from the original $2.50 \mathrm{~g}(50 \%)$. The mass lost during the treatment was $15 \%$. Assuming, all mass lost was due to evaporation, 1.21 grams of liquid was evaporated during the test. The remaining 6.88 grams of liquid has a specific gravity of $1.0717 \mathrm{~g} / \mathrm{mL}$, and therefore, a volume of $6.42 \mathrm{~mL}$. The organics recovered from the evaporation of $1 \mathrm{~mL}$ of liquid was $172.9 \mathrm{mg}$. The amount of resin dissolved in the liquid is calculated by $6.42 \mathrm{~mL}$ x $172.9 \mathrm{mg} / \mathrm{mL}$ x $1 \mathrm{~g} / 1000 \mathrm{mg}=1.11 \mathrm{~g}$ (44\%). The mass balance due to solid and liquid was $94 \%$. 
WSRC-TR-2000-00304, Rev. 0

SRT-RPP-2000-00005

Rev. 0

\section{Prolonged Contacting of SuperLig ${ }^{\circledR} 644$ resin with $5 M$ nitric acid solution at ambient temperature}

For this RSST test ( $0.4 \mathrm{~g}$ resin), a larger-scale beaker test (10 g acid) was conducted simultaneously. The larger-scale beaker test was used to visually monitor the dissolution of resin. The RSST was run continuously and the Parr bomb was kept sealed until termination of the test at 21 days. The target liquid:solid ratio of about 25:1 will be used for both RSST-scale and the larger-scale beaker tests. Resin was contacted with 5M nitric acid for 21 days in the RSST. Solid, liquid, and gaseous degradation products were analyzed.

Test 8. RSST test. SuperLig ${ }^{\circledR} 644$ resin ( 0.4 grams) and 5 molar nitric acid (10.0 grams) were loaded into the RSST, and containment was closed without backpressure. The system was slowly heated from ambient temperature to $25 \pm 5{ }^{\circ} \mathrm{C}$ at a rate of $15^{\circ} \mathrm{C} / \mathrm{hr}$ $\left(0.25^{\circ} \mathrm{C} / \mathrm{min}\right)$, and held at $25.0 \pm 1.1^{\circ} \mathrm{C}$ until the test was terminated.

The objective of a similar large-scale test (not performed in the RSST) was solely to observe the reaction to determine when dissolution is complete, so that the activity in the concurrent RSST test could be inferred. The larger-scale beaker test contained SuperLig ${ }^{\circledR} 644$ resin (4 grams) and 5 molar nitric acid (100 grams), and was rapidly stirred with a magnetic stir bar. The beaker was covered with a watchglass and visually monitored. The beaker-scale test did not completely dissolve the resin in 21 days. The RSST test was terminated, and the off-gas was collected in a Tedlar ${ }^{\mathrm{TM}}$ bag.

The RSST reaction profiles shown in Figures 19-22 characterize the reactivity of the system. A slow steady pressure rise is evidence of gas evolution associated with slow degradation.

The mass loss in the test was $4 \%$, and is attributed to solvent evaporation and condensation on the sides of the vessel. The residue recovered from the evaporation of 1 $\mathrm{mL}$ of liquid was $32.6 \mathrm{mg}$. The mass of resin that dissolved was $0.313 \mathrm{~g}(78 \%)$. The recovered solid had a mass of $0.0843 \mathrm{~g}(21 \%)$ after drying in vacuum at 40 to $50{ }^{\circ} \mathrm{C}$ for 8 hours. The mass balance due to liquid and solid recovery was $99 \%$. The gas was analyzed by VOA (Table 3, 8-gas) and the liquid was analyzed by SVOC (Table 3, 8-liquid). The SVOC analysis indicated several peaks that had fragmentation patterns consistent with ethers or other oxygenated organics. Since the structure of the resin material is proprietary and not known to SRTC, a positive identification of soluble degradation products was not feasible, and the concentration shown $(4.9 \mathrm{mg} / \mathrm{L})$ is the sum total of the estimated concentrations. The presence of toluene was also identified in the "blank acid" run of the $\mathrm{RSST}^{3}$, and likely originates from degradation of polymeric internals, such as insulation. Dried solids and evaporated and dried liquid samples were analyzed by DSC (Table 4, Figures 36 and 37). The analysis of the gas, liquid and solid samples identified no reactive compounds. In addition, VOA analyses were performed on blank runs B1_N2 (nitrogen in Tedlar ${ }^{\circledR}$ bag) and B2_air (air in Tedlar ${ }^{\circledR}$ bag), and the results are shown in Table 3. 
WSRC-TR-2000-00304, Rev. 0

SRT-RPP-2000-00005

Rev. 0

Ion Cyclotron Mass Spectrometry was performed on yellow liquid from Test 8 (partial dissolution) is shown in Figure 31. The mass spectrum contained three sets of peaks: 938$939,640-681$, and $165-281 \mathrm{~m} / \mathrm{z}$. The three sets of peaks are consistent with the sequential fragmentation of a resin copolymer into smaller units. However, no specific compounds could be identified.

Preparation of a SuperLig ${ }^{\circledR} 644$ solution for neutralization test. SuperLig ${ }^{\circledR} 644$ resin (4 grams) was dissolved in 5 molar nitric acid (100 grams) by heating at about $90{ }^{\circ} \mathrm{C}$ for 8 hours.

ICMS performed on yellow liquid from Test 8 (complete dissolution) is shown in Figure 32. The mass spectrum contained two broad distributions of peaks $(\sim 200 \mathrm{~m} / \mathrm{z}$ and $\sim 550 \mathrm{~m} / \mathrm{z}$ ). The multitude of peaks suggests a more general degradation occurred under these harsher (higher temperature) conditions relative to the "partial dissolution". However, no specific compounds could be identified.

Beaker Neutralization Test (5-mL). A 5-mL aliquot of "dissolved SuperLig ${ }^{\circledR} 644$ solution" ( $8 \mathrm{~L}=8$ liquid) was placed in a beaker, and 5 molar sodium hydroxide was added to achieve $\mathrm{pH} 12-13$ (by $\mathrm{pH}$ paper). For the RSST test, a 5-mL aliquot of "SuperLig ${ }^{\circledR} 644$ solution" was loaded into the RSST. The amount of sodium hydroxide required to attain $\mathrm{pH} 12-13$ in the 5-mL beaker test was added externally to a sealed Parr bomb. A syringe was used to force the sodium hydroxide through an extension tube into the test cell. Sample was not ejected during the neutralization tests, and no foaming or precipitation was observed.

The neutralization $(\mathrm{N})$ test of the $8 \mathrm{~L}$ solution was performed four times $(8 \mathrm{~L}-\mathrm{N} 1,8 \mathrm{~L}-\mathrm{N} 2$, 8L-N3 and 8L-N4) with $\mathrm{pH} 7$ being exceeded twice, as shown in Table 5. No foaming was observed during the neutralization reaction. The results indicate that little nitric acid was consumed in the dissolution, as the equal volume of $5 \mathrm{M}$ sodium hydroxide solution very nearly neutralized the "dissolved SuperLig ${ }^{\circledR} 644$ solution". Interestingly, a distinct orange-yellow to golden/brown color change occurred at approximately $\mathrm{pH} 7$.

The RSST profiles in Figures 23-26 are consistent with a rapid, exothermic acid-base neutralization reaction. Figure 24 shows a small net pressure change that is associated with the addition of a liquid to a sealed system.

\section{Prolonged Contacting of SuperLig ${ }^{\circledR} 644$ resin with deionized water at intermediate temperature}

Work described in this section was intended to determine if the resin will completely dissolve in deionized water at $60{ }^{\circ} \mathrm{C}$.

Test 9. SuperLig ${ }^{\circledR} 644$ resin ( 0.4 grams) and deionized water (10.0 grams) were loaded into the RSST, and containment was closed without backpressure. The system was heated from ambient to $60{ }^{\circ} \mathrm{C}$ at a rate of $15^{\circ} \mathrm{C} / \mathrm{hr}\left(0.25{ }^{\circ} \mathrm{C} / \mathrm{min}\right)$, and held at about $60^{\circ} \mathrm{C}$ for one week. A same-scale beaker test did not completely dissolve during the test period. 
The off-gas was analyzed by VOA (Table 3, 9-gas). The dried solids and the evaporated and dried liquid samples were analyzed by DSC (Table 4, Figures 38 and 39). The analysis of the gas, liquid and solid samples identified no reactive compounds.

The RSST reaction profiles in Figures 27-30 reflect temperature changes due to daily shutdown and restarts, however, no exotherms or net pressure change was identified. As expected, this evidence suggests gases were not generated from the contact of water and SuperLig ${ }^{\circledR} 644$ resin.

The $17 \%$ mass lost in the test was attributed to solvent evaporation ( $9.3 \mathrm{~g}$ total mass remaining) (which condenses on the vessel wall). The residue recovered from the evaporation of $1 \mathrm{~mL}$ of liquid was $28.4 \mathrm{mg}$. The mass of resin that dissolved was $0.231 \mathrm{~g}$ (55\%). The recovered solid had a mass of $0.1790 \mathrm{~g}(45 \%)$ after air and vacuum drying at room temperature. The mass balance of resin due to liquid and solid recovery was $100 \%$. The gas was analyzed by VOA (Table 3, 9-gas), and the dried solids and evaporated and dried liquid samples were analyzed by DSC (Table 4). The analysis of the gas, liquid and solid samples identified no reactive compounds.

ICMS performed on brown liquid from Test 9 is shown in Figure 33. The mass spectrum contains a single peak at $223 \mathrm{~m} / \mathrm{z}$. Since this is the $(\mathrm{M}+1)^{+}$peak, the molecular weight of this single component is $222 \mathrm{grams} / \mathrm{mole}$. However, the identity of this component could not be determined.

Table 3. Analysis of Gases and Liquid Residue Using VOA, SVOA and SVOC

\begin{tabular}{|c|c|c|c|c|c|c|c|}
\hline & \multicolumn{3}{|c|}{ Analyte, $\mathrm{mg} / \mathrm{L}$} & \multicolumn{3}{|c|}{ Gas Concentrations, \% } & \multirow[b]{2}{*}{ Method } \\
\hline $\begin{array}{l}\text { Test } \\
\text { No. }\end{array}$ & $\begin{array}{c}\text { Aliphatic } \\
\text { Hydrocarbons }\end{array}$ & $\begin{array}{l}\text { Ethers and } \\
\text { Oxygenated } \\
\text { Organics }\end{array}$ & Toluene & $\mathrm{N}_{2}$ & $\mathrm{CO}_{2}$ & $\mathrm{~N}_{2} \mathrm{O}$ & \\
\hline 1-gas & $\overline{0.13}$ & $\overline{-}$ & $\overline{0.11}$ & $99 \%^{+}$ & - & - & $\overline{\mathrm{VOA}}$ \\
\hline 2-gas & 0.024 & 0.035 & 0.061 & $99 \%+$ & - & - & VOA \\
\hline 8-gas & 0.21 & 0.052 & 0.2 & 96 & 3.0 & 1.0 & VOA \\
\hline 9-gas & 0.088 & 0.025 & 0.097 & $99 \%+$ & 0.28 & & VOA \\
\hline $\mathrm{B} 1 \mathrm{~N} 2$ & - & 0.031 & - & $99 \%+$ & & & $\overline{\mathrm{VOA}}$ \\
\hline B2_air & - & 0.020 & - & $99 \%+$ & 0.033 & & $\mathrm{VOA}$ \\
\hline 8-liquid & & 4.9 & & & & & SVOC \\
\hline
\end{tabular}

$1=$ Resin and $1 \mathrm{M} \mathrm{NaMnO}_{4}$

$2=$ Resin and $1 \mathrm{M} \mathrm{NaMnO}_{4}$

$8=$ Resin and $5 \mathrm{M}$ nitric heated to $25^{\circ} \mathrm{C}$

$9=$ Resin and water heated to $60^{\circ} \mathrm{C}$

B1_N2 = blank run 1 containing nitrogen

B2_air = blank run 2 containing air 
WSRC-TR-2000-00304, Rev. 0

SRT-RPP-2000-00005

Rev. 0

Table 4. Analysis of Solid and Liquid Residue DSC

\begin{tabular}{|c|c|c|}
\hline Test No. & $\begin{array}{c}\text { Peak Temperature } \\
{ }^{0} \mathrm{C}\end{array}$ & $\begin{array}{c}\text { Peak Height } \\
\mathrm{W} / \mathrm{g}\end{array}$ \\
\hline \multirow[t]{4}{*}{ 7-liquid } & 93.8 & -2.5 \\
\hline & 107 & -0.07 \\
\hline & 325 & 1.48 \\
\hline & 356 & 0.3 \\
\hline \multirow[t]{6}{*}{7 -solid } & 104 & -0.44 \\
\hline & 327 & -0.17 \\
\hline & 404 & 0.7 \\
\hline & 410 & 0.47 \\
\hline & 415 & 0.54 \\
\hline & 423 & 0.18 \\
\hline \multirow[t]{5}{*}{ 8-liquid } & 91.1 & -0.226 \\
\hline & 110 & 0.548 \\
\hline & 132 & -0.8 \\
\hline & 336 & 2.6 \\
\hline & 393 & 2.68 \\
\hline 8-solid & 87.5 & -0.378 \\
\hline \multirow[t]{7}{*}{ 9-liquid } & 110 & -3.2 \\
\hline & 150 & -0.47 \\
\hline & 301 & 0.23 \\
\hline & 336 & 1.3 \\
\hline & 346 & 0.81 \\
\hline & 356 & 1.02 \\
\hline & 502 & 0.52 \\
\hline \multirow[t]{4}{*}{ 9-solid } & 119 & -0.629 \\
\hline & 329 & -0.2 \\
\hline & 400 & 0.17 \\
\hline & 442 & 0.381 \\
\hline
\end{tabular}

Table 5. Caustic Neutralization of SuperLig ${ }^{\circledR} 644$ solution

\begin{tabular}{|c|c|c|c|c|c|}
\hline Test & $\begin{array}{c}\text { Mass of 5.000 } \mathbf{~ m L} \\
\text { of SL644 (aq) }\end{array}$ & $\begin{array}{c}\text { Mass of } \\
\mathbf{5 M ~ N a O H} \\
\mathbf{g}\end{array}$ & $\begin{array}{c}\text { Final } \\
\mathbf{~}\end{array}$ & $\begin{array}{c}\text { SH } \\
\text { Solution } \\
\text { Color }\end{array}$ & $\begin{array}{c}\text { Evidence of } \\
\text { Solids, Sample } \\
\text { Ejected or Foam }\end{array}$ \\
\hline 8L-N1 & 5.895 & 6.1 & 2 & orange/yellow & None \\
\hline 8L-N2 & 5.916 & 6.7 & 4 & golden/yellow-brown & None \\
\hline 8L-N3 & 5.907 & 6.7 & $>11$ & golden/brown & None \\
\hline 8L-N4 & 5.896 & 7.3 & $>11$ & golden/brown & None \\
\hline
\end{tabular}


WSRC-TR-2000-00304, Rev. 0

SRT-RPP-2000-00005

Rev. 0

\section{CONCLUSIONS}

This task addressed four items related to SuperLig ${ }^{\circledR} 644$ ion exchange resin stability under nominal to extreme conditions.

1. A process upset analysis of resin in contact with 1 molar sodium permanganate at 25 and $40{ }^{\circ} \mathrm{C}$ identified runaway reaction behavior that was characterized by acute selfheating and sample ejection, however, only condensable gas was evolved. An analogous test of the resin-permanganate reaction under $2000 \mathrm{kPa}$ prevented sample ejection, displayed a temporary pressure rise, but also showed no net evolution of noncondensable gases.

2. A simulation of the accelerated aging of resin during normal dilute acid regeneration operations identified no measurable reactivity. The 24 -hour treatment at $90{ }^{\circ} \mathrm{C}$ in $0.5 \mathrm{M}$ nitric acid dissolved $44 \%$ of the resin. One precaution is that the addition of even dilute nitric acid to dry resin results in rapid foaming, although no self-heating was observed.

3. The behavior of resin in $5 \mathrm{M}$ nitric acid at ambient temperatures was characterized as a slow steady evolution of non-condensable gases $\left(\mathrm{NO}_{\mathrm{x}}\right.$ and $\left.\mathrm{CO}_{2}\right)$, and $78 \%$ of the resin dissolved after 21 days. Caustic neutralization of a "SuperLig ${ }^{\mathbb{B}} 644$ resin solution" was characterized as a rapid exothermic reaction without foaming, bubbling, or precipitation.

4. Resin exposure to water at $60{ }^{\circ} \mathrm{C}$ showed no measurable gas evolution, and dissolved $55 \%$ if the resin after 7 days.

5. Differential scanning calorimetry (DSC) analysis of solid and liquid residues from nitric acid and water tests showed small heat flows, evidence that the potential reactivity of these resin-nitric acid reaction products is small to negligible. Volatile organic analysis (VOA) did not identify any reactive compounds in the gaseous degradation products. Semi-volatile organic analysis (SVOA) of a liquid residue did not identify typical low molecular weight resin degradation products. For the detection of low molecular weight organic acids, liquid chromatography-mass spectrometry (LC-MS) of samples was performed. Since the resin structure is proprietary, the mass peaks could not be assigned to specific compounds.

6. Dissolution of $55 \%$ of the resin in warm water was not anticipated. A portion of the mass loss may is attributable to dissolution of potassium, which was recently identified by IBC Advanced Technologies as present in this resin batch. The measured concentration of potassium is $15.5 \mathrm{wt} \%$ of the as-received mass. It is also known that approximately $8 \%$ of the as-received mass is due to absorbed moisture, which would have been removed in this experiment. Since the solution is colored, it may also contain low molecular weight polymerized ligand. The possibility of the presence of a low molecular weight polymer has implications for the fate of the wash solution. If the polymer contains the cesiumbinding ligand, it may bind the cesium in solution, prohibiting absorption by the column. 
WSRC-TR-2000-00304, Rev. 0

SRT-RPP-2000-00005

Rev. 0

The resin wash solutions should not be combined with ion exchange feed solution until it can be proved that this does not occur.

The objective of this work was to characterize the reactivity of SuperLig ${ }^{\circledR} 644$ and identify a margin of safety for plant process operations. These results are intended to be used by the design authority, along with additional testing that has been performed at SRTC and elsewhere, to determine the impact on facility design safety. The design authority will develop the bounding facility conditions (e.g., safe concentration of permanganate solution, rupture disk capacity, etc.). In summary, this work characterized the reactivity SuperLig ${ }^{\circledR} 644$ ion exchange resin under various conditions as part of the validation of waste treatment technologies to be employed by the Hanford River Protection Project. 
WSRC-TR-2000-00304, Rev. 0

SRT-RPP-2000-00005

Rev. 0

Figure 3. SuperLig ${ }^{\circledR} 644$ resin and 1 molar sodium permanganate At 0 PASCAL: Temperature VS. Time

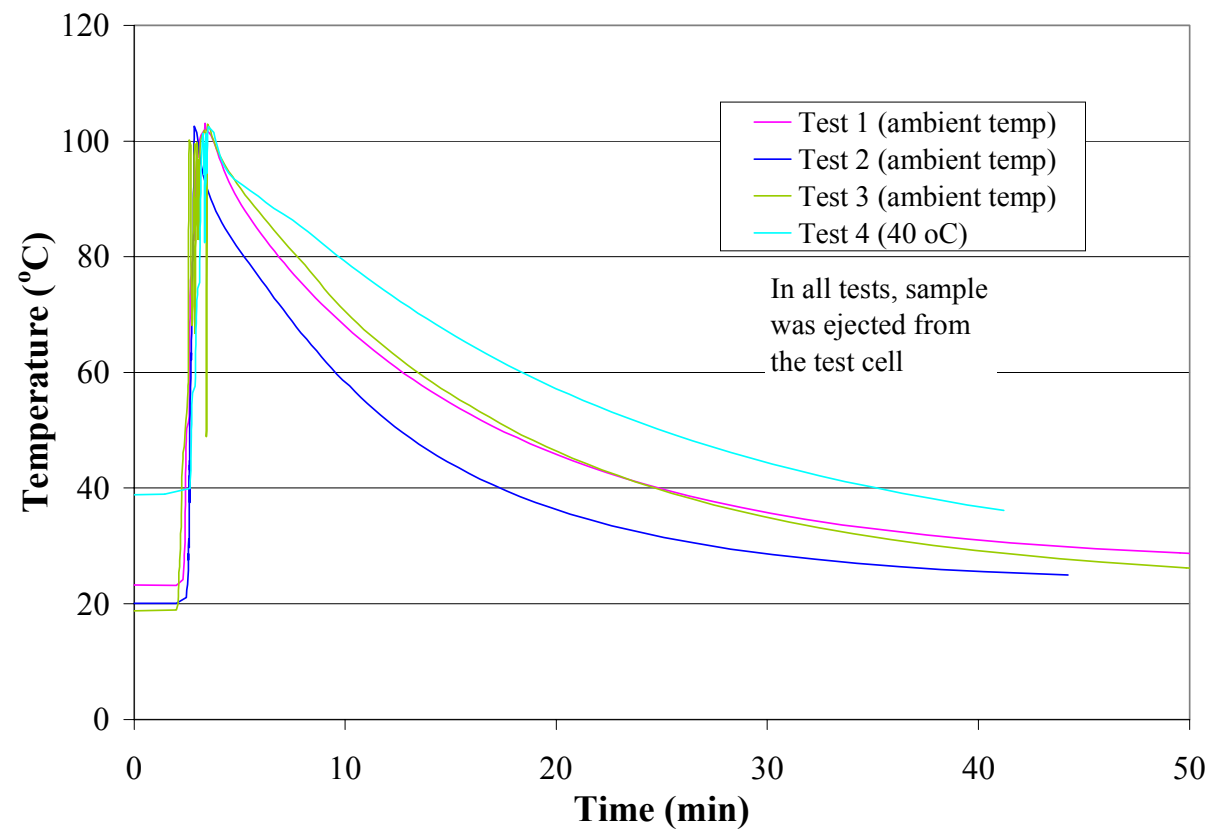

Figure 4. SuperLig ${ }^{\circledR} 644$ resin and 1 molar sodium permanganate 0 PASCAL: PRESSURE VS. TIME

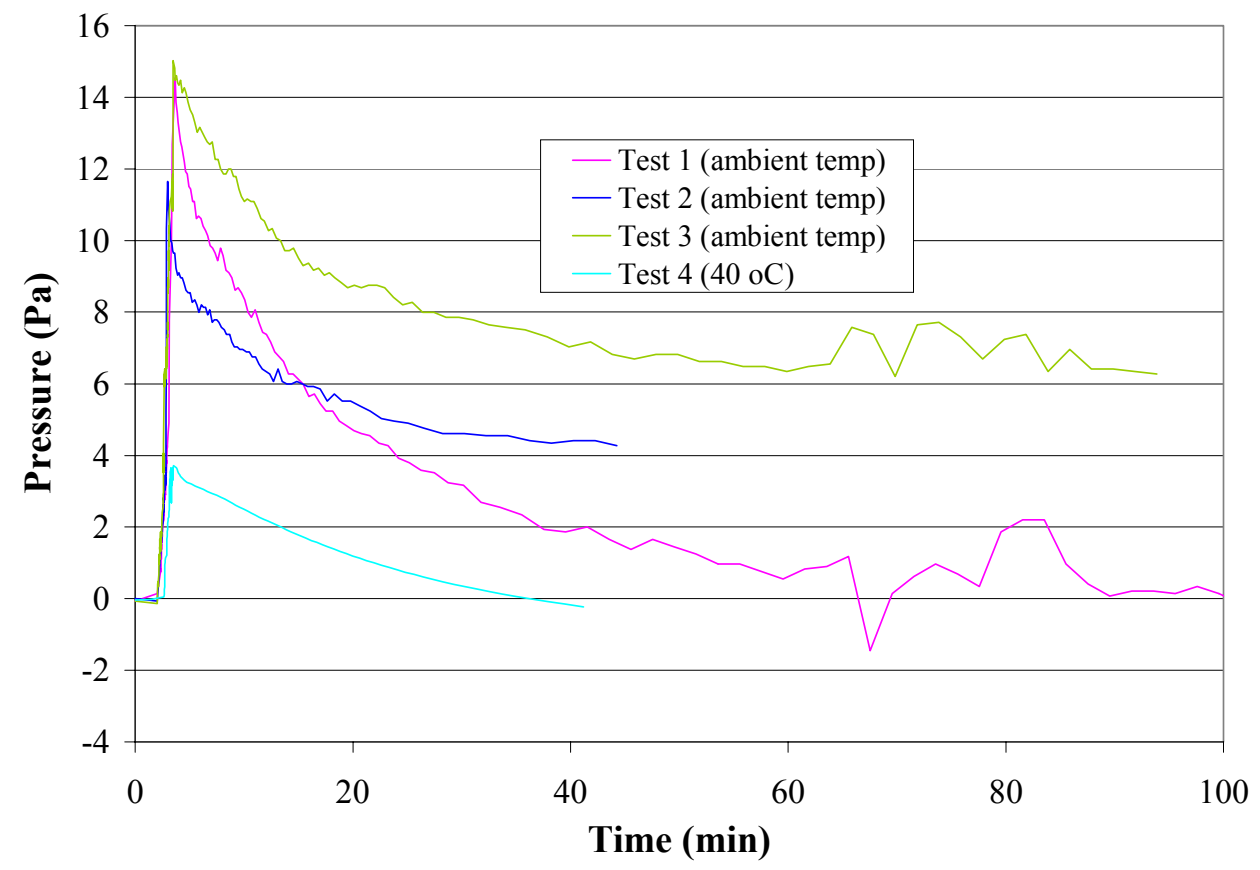


WSRC-TR-2000-00304, Rev. 0

SRT-RPP-2000-00005

Rev. 0

Figure 5. SuperLig ${ }^{\circledR} 644$ resin and 1 molar sodium permanganate At 0 PASCAL: SELF-HeAting VS. TEMPERATURE

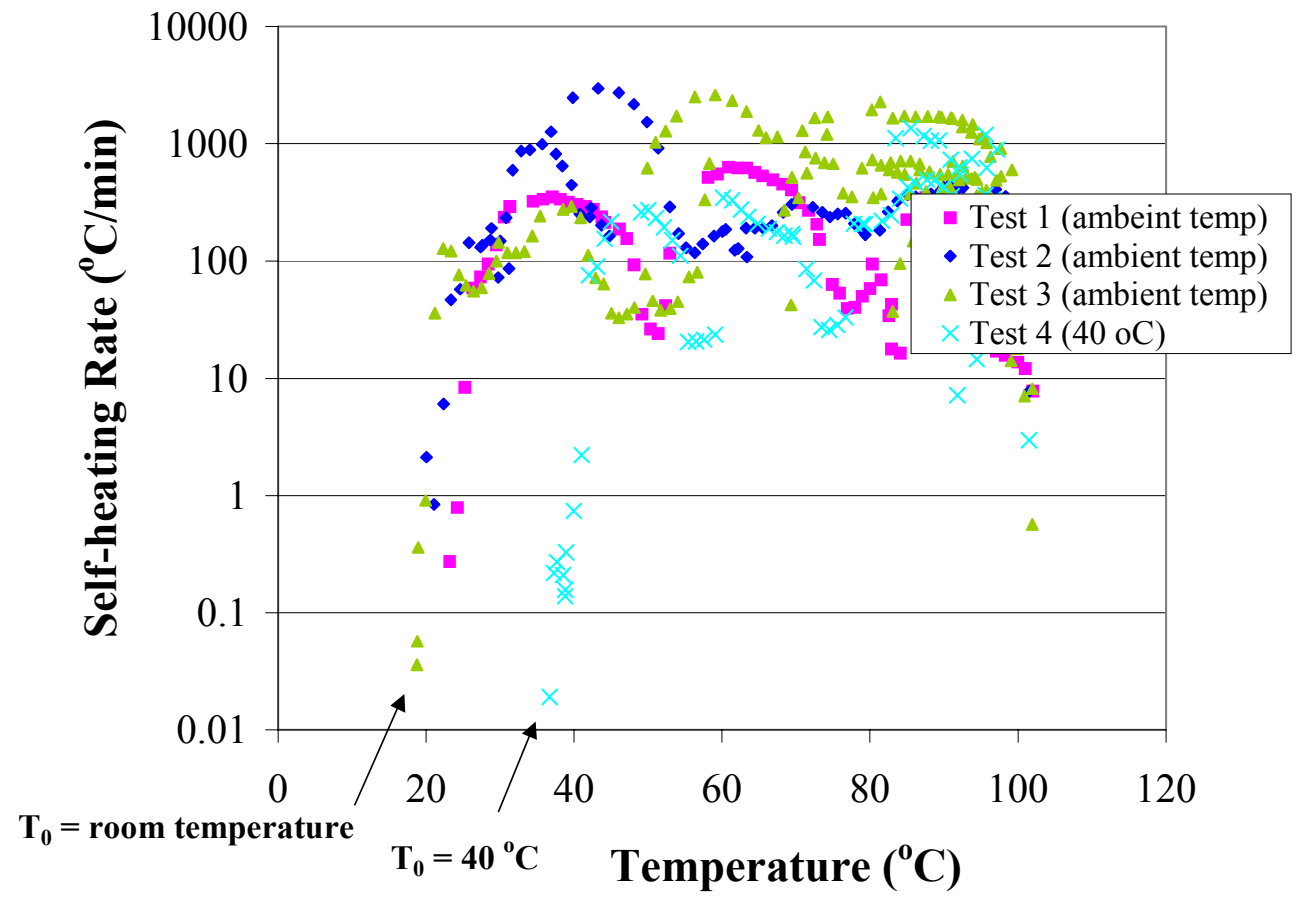

Figure 6. SuperLig ${ }^{\circledR} 644$ resin and 1 molar sodium permanganate at 0 Pascal: Pressure Rate Vs. Temperature

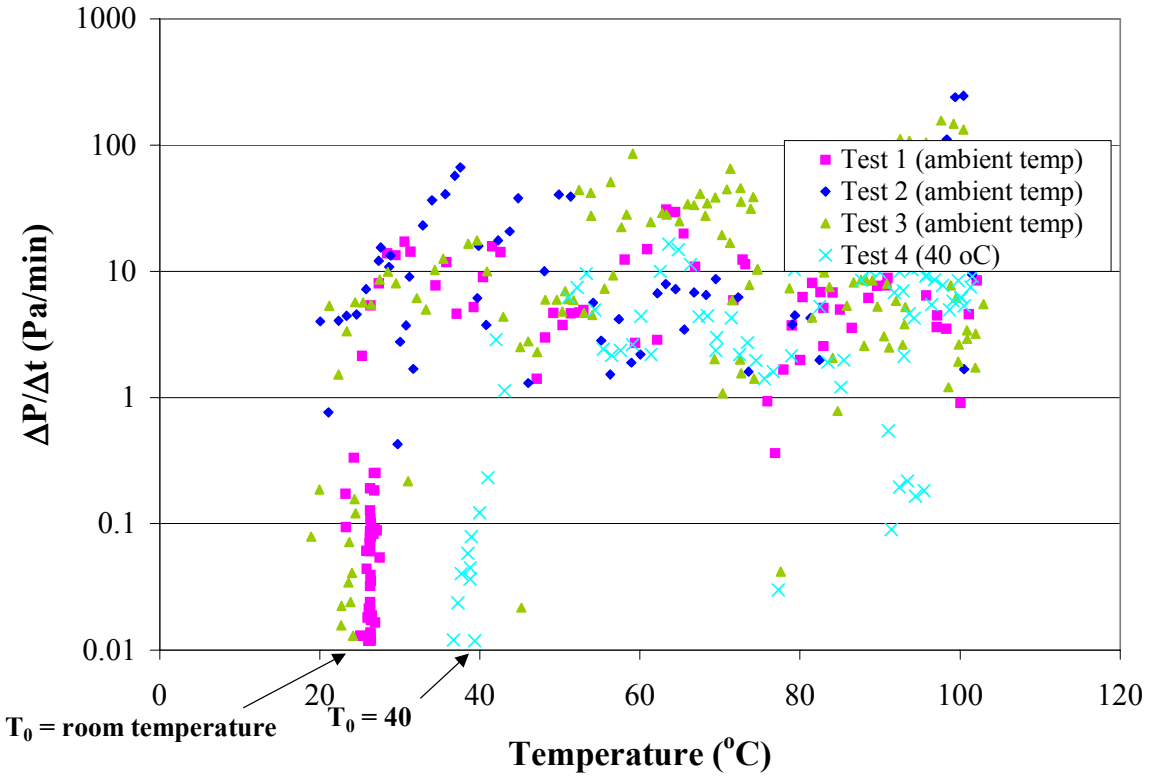


WSRC-TR-2000-00304, Rev. 0

SRT-RPP-2000-00005

Rev. 0

Figure 7. SuperLig $^{\circledR} 644$ resin and Water

AT 2000 KilOPASCAL: TEMPERATURE VS. Time

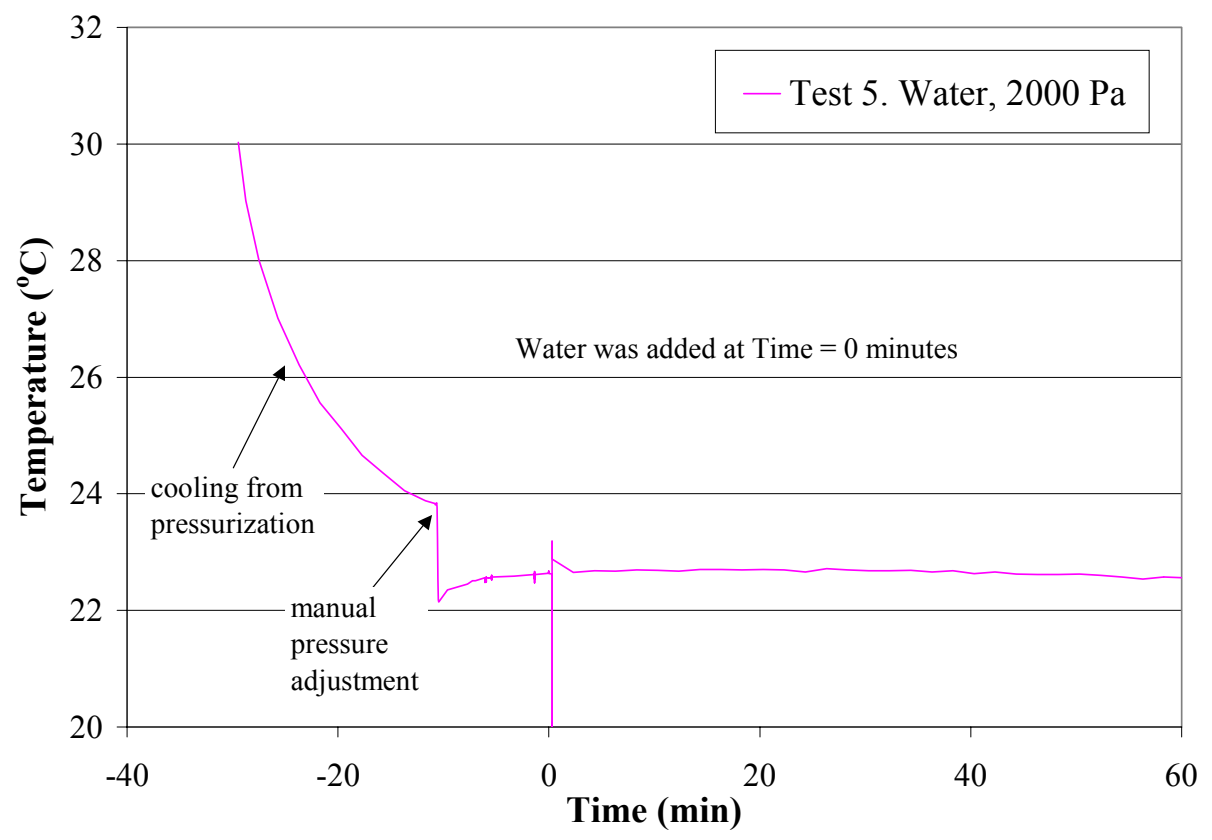

Figure 8. SuperLig $^{\circledR} 644$ resin and Water

at 2000 Kilopascal: Pressure Vs. Time

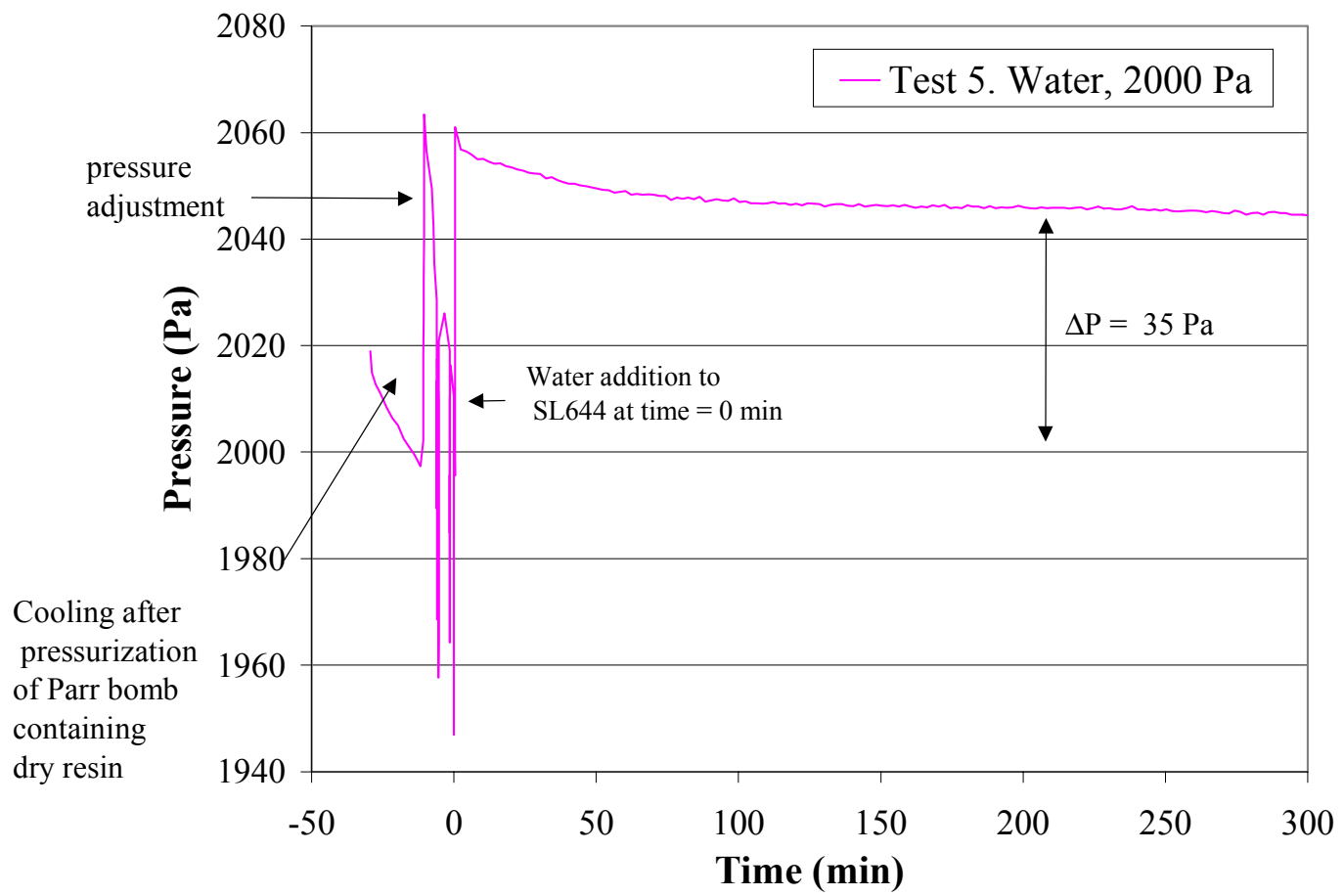


WSRC-TR-2000-00304, Rev. 0

SRT-RPP-2000-00005

Rev. 0

Figure 9. SuperLig ${ }^{\circledR} 644$ resin and Water

at 2000 KilopasCaL: SelF-HEATING Vs. TEMPERATURE

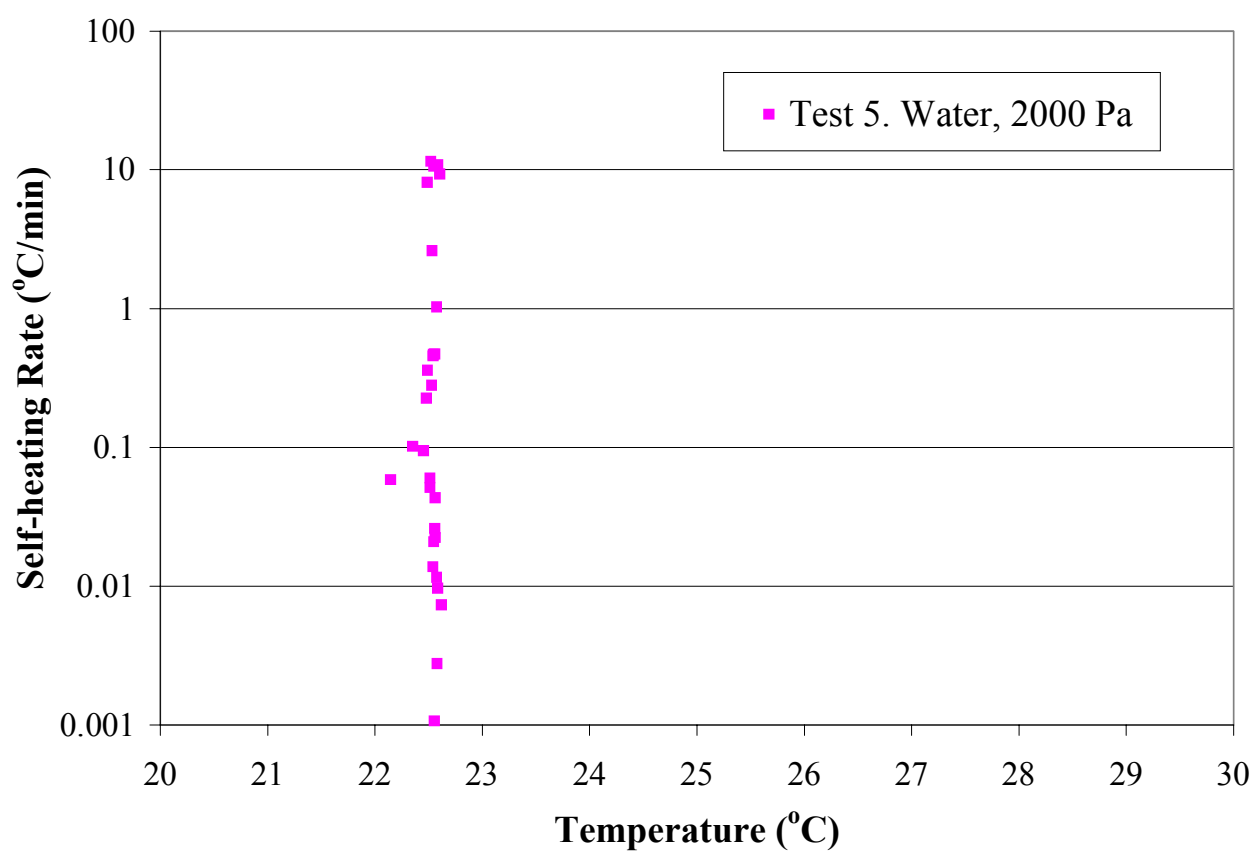

Figure 10. SuperLig ${ }^{\circledR} 644$ resin and Water at 2000 Kilopascal: Pressure Rate vs. Temperature

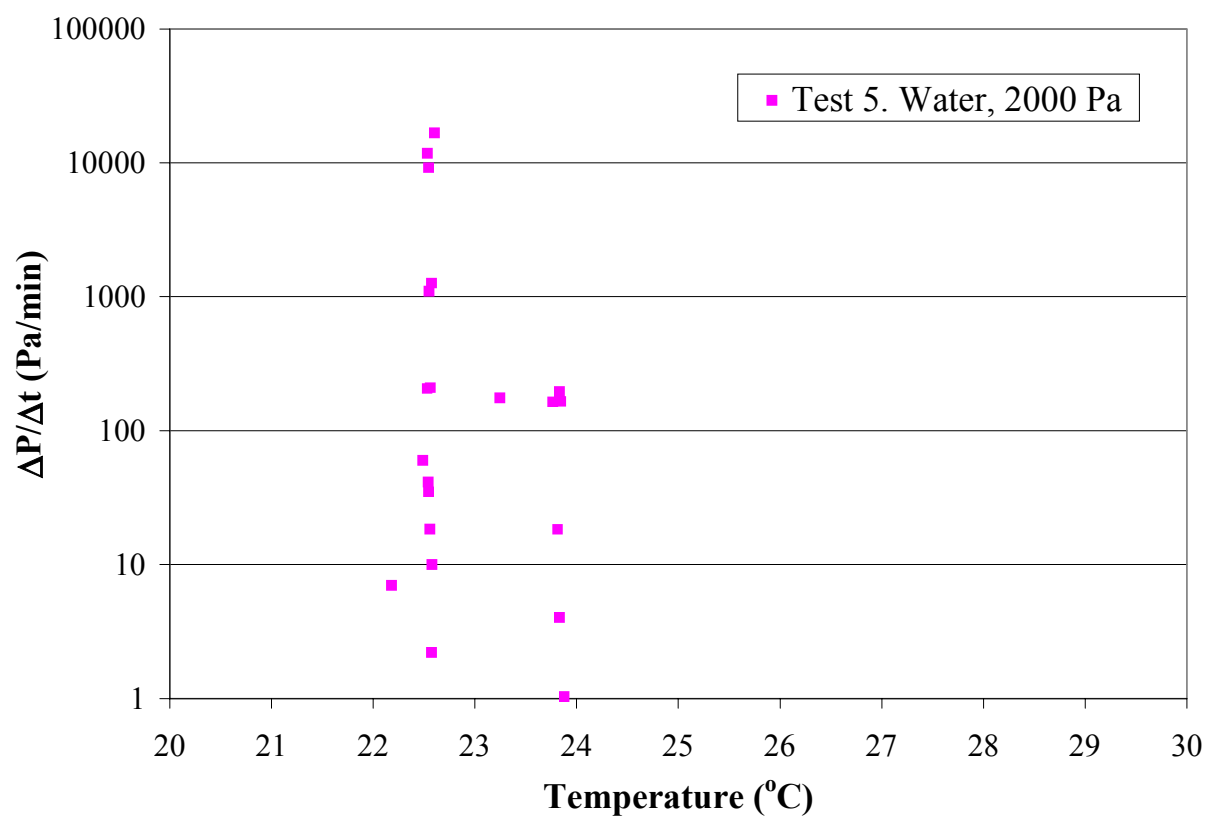


WSRC-TR-2000-00304, Rev. 0

SRT-RPP-2000-00005

Rev. 0

Figure 11. SuperLig ${ }^{\circledR} 644$ resin and 1 molar sodium permanganate AT 2000 PA: TEMPERATURE VS. TIME

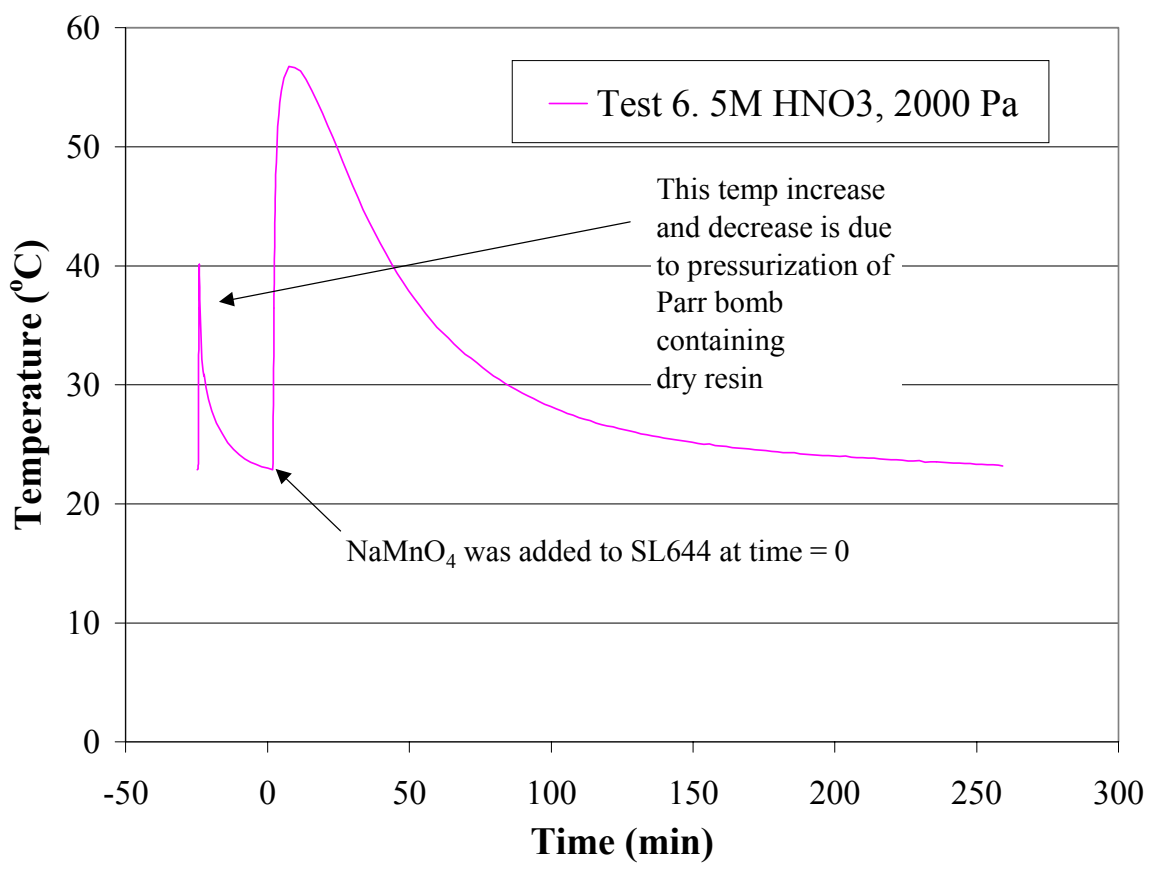

Figure 12. SuperLig ${ }^{\circledR} 644$ resin and 1 molar sodium permanganate AT 2000 PA: PRESSURE VS. TIME

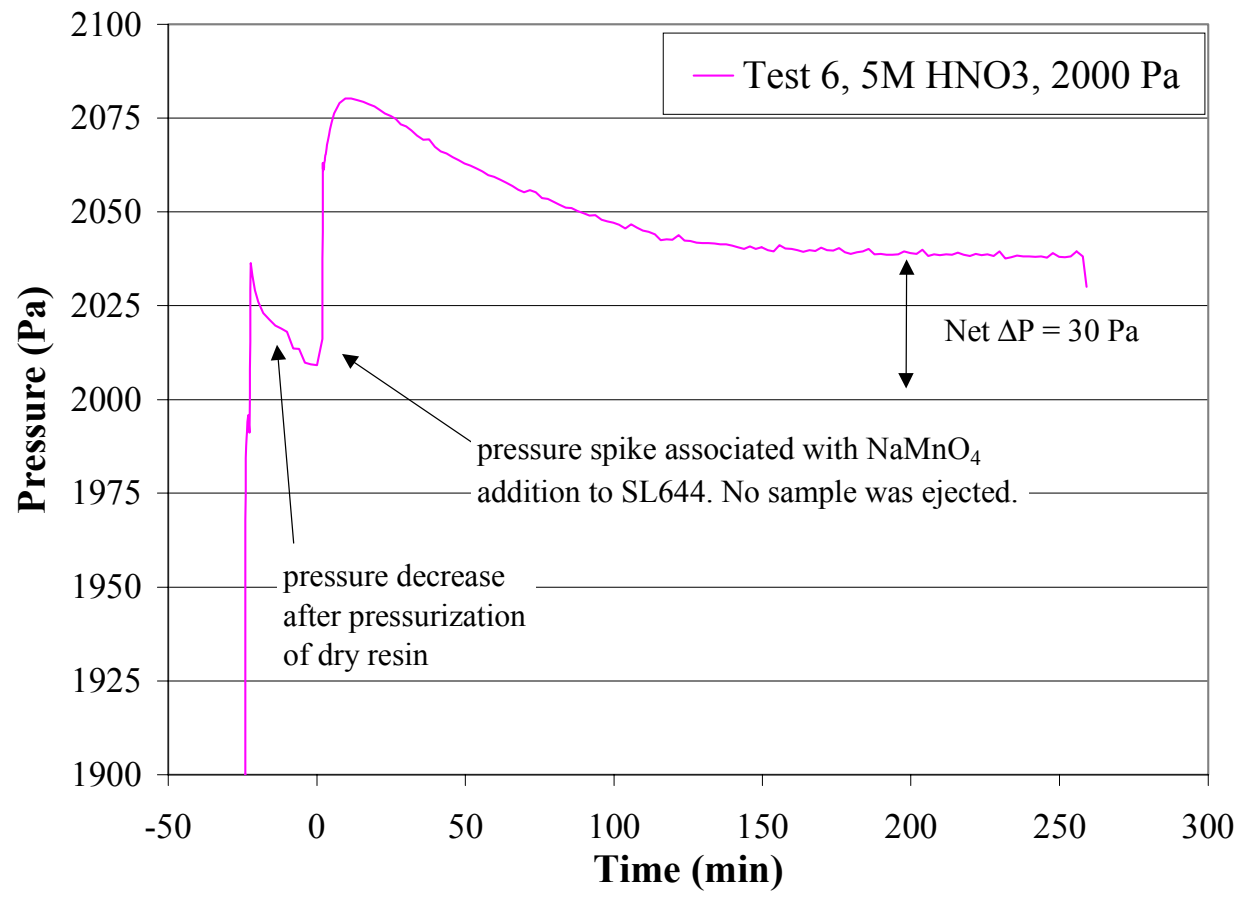


WSRC-TR-2000-00304, Rev. 0

SRT-RPP-2000-00005

Rev. 0

Figure 13. SuperLig ${ }^{\circledR} 644$ resin and 1 molar sodium permanganate AT 2000 PA: SELF-HEATING VS. TEMPERATURE

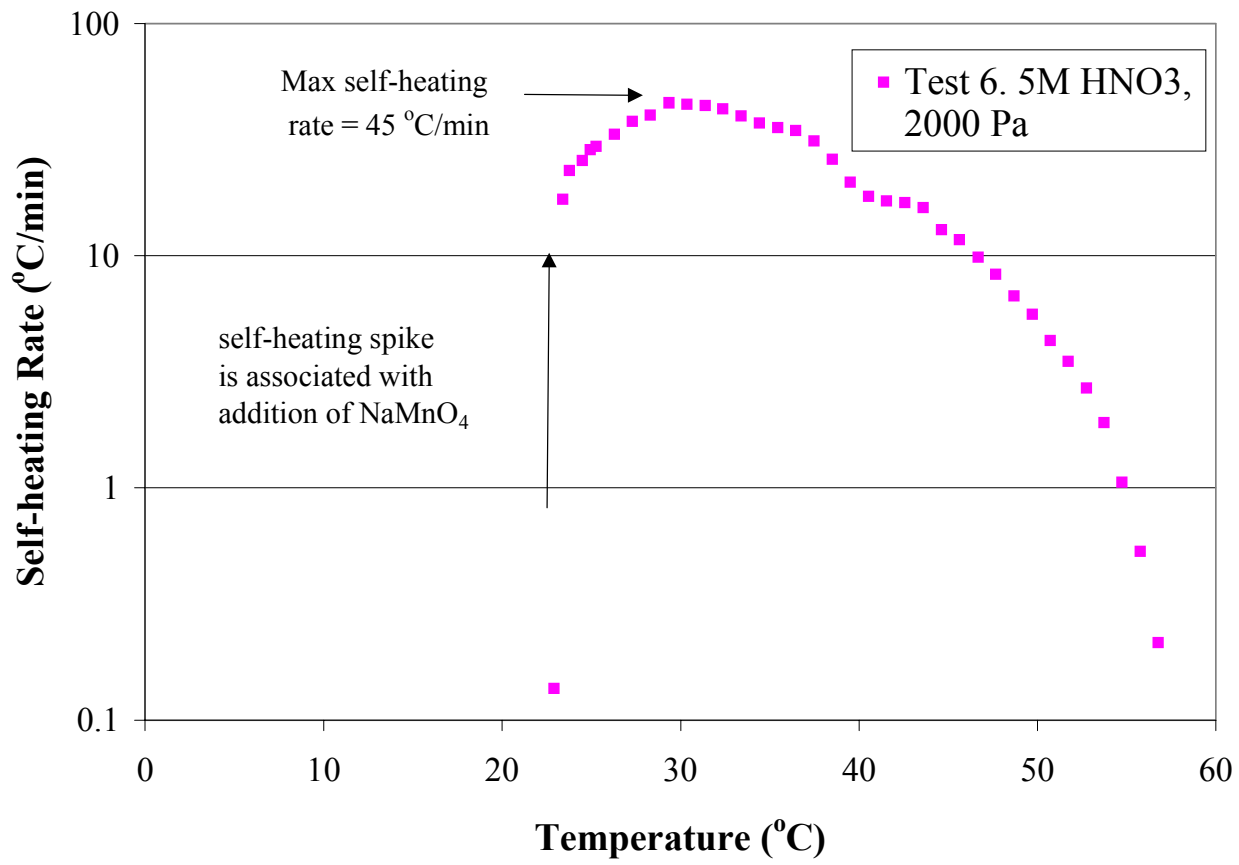

FigURE 14. SUPERLIG ${ }^{\circledR} 644$ RESIN AND 1 MOLAR SODIUM PERMANGANATE At 2000 PA: Pressure RATE VS. TEMPERATURE

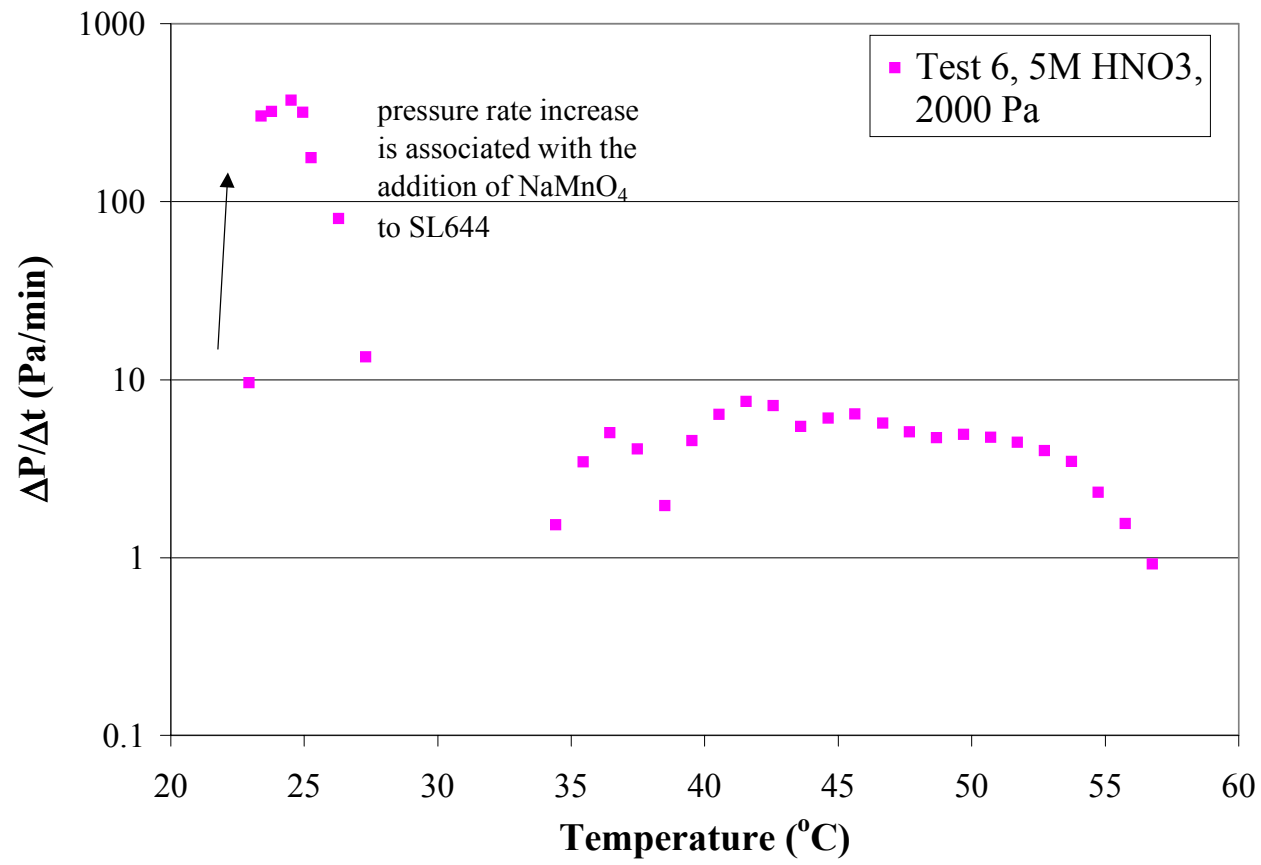


WSRC-TR-2000-00304, Rev. 0

SRT-RPP-2000-00005

Rev. 0

Figure 15. SuperLig ${ }^{\circledR} 644$ resin and 0.5 molar nitric Acid

At 0 PAscal: Temperature Vs. TIME

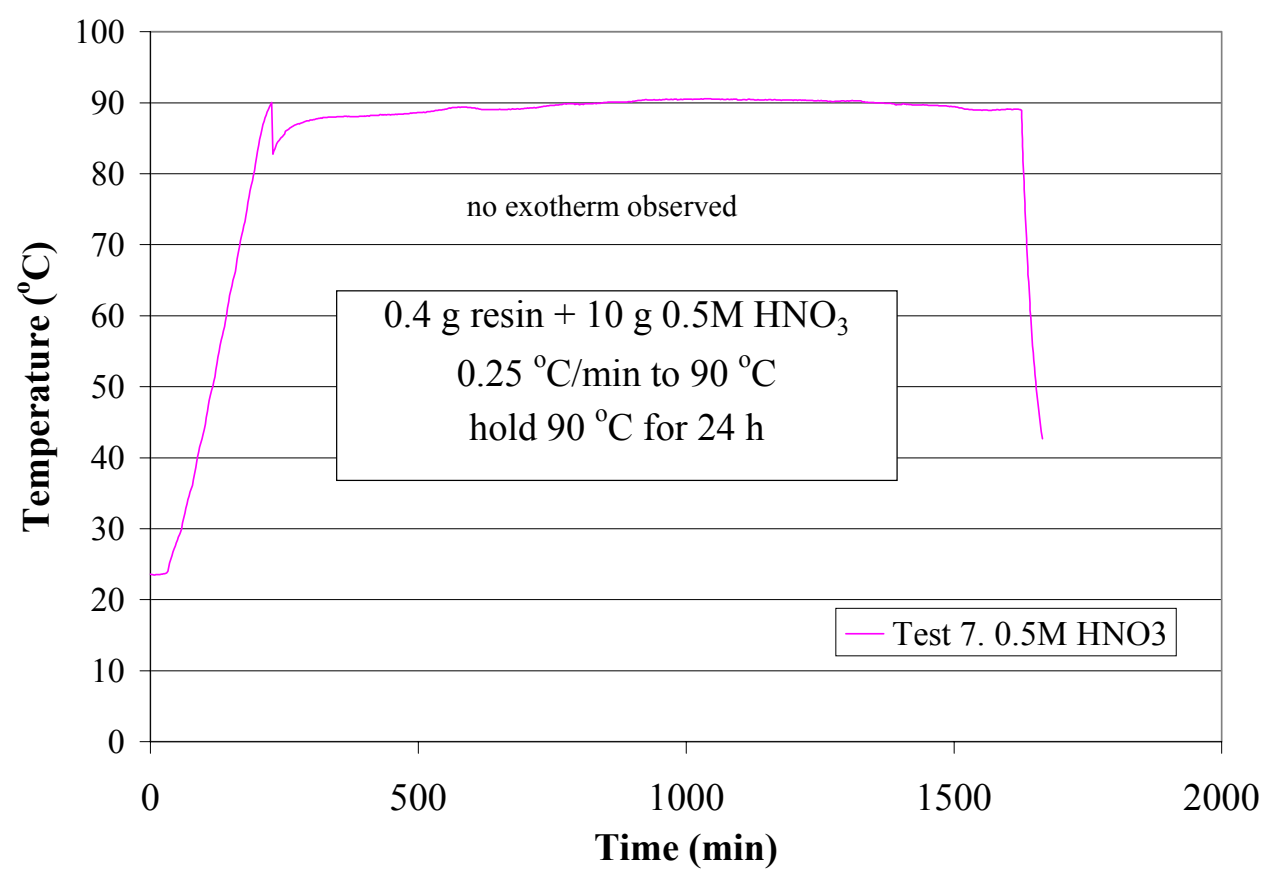

FigURE 16. SUPERLIG ${ }^{\circledR} 644$ RESIN AND 0.5 MOLAR NITRIC ACID at 0 PASCAL: PRESSURE VS. Time

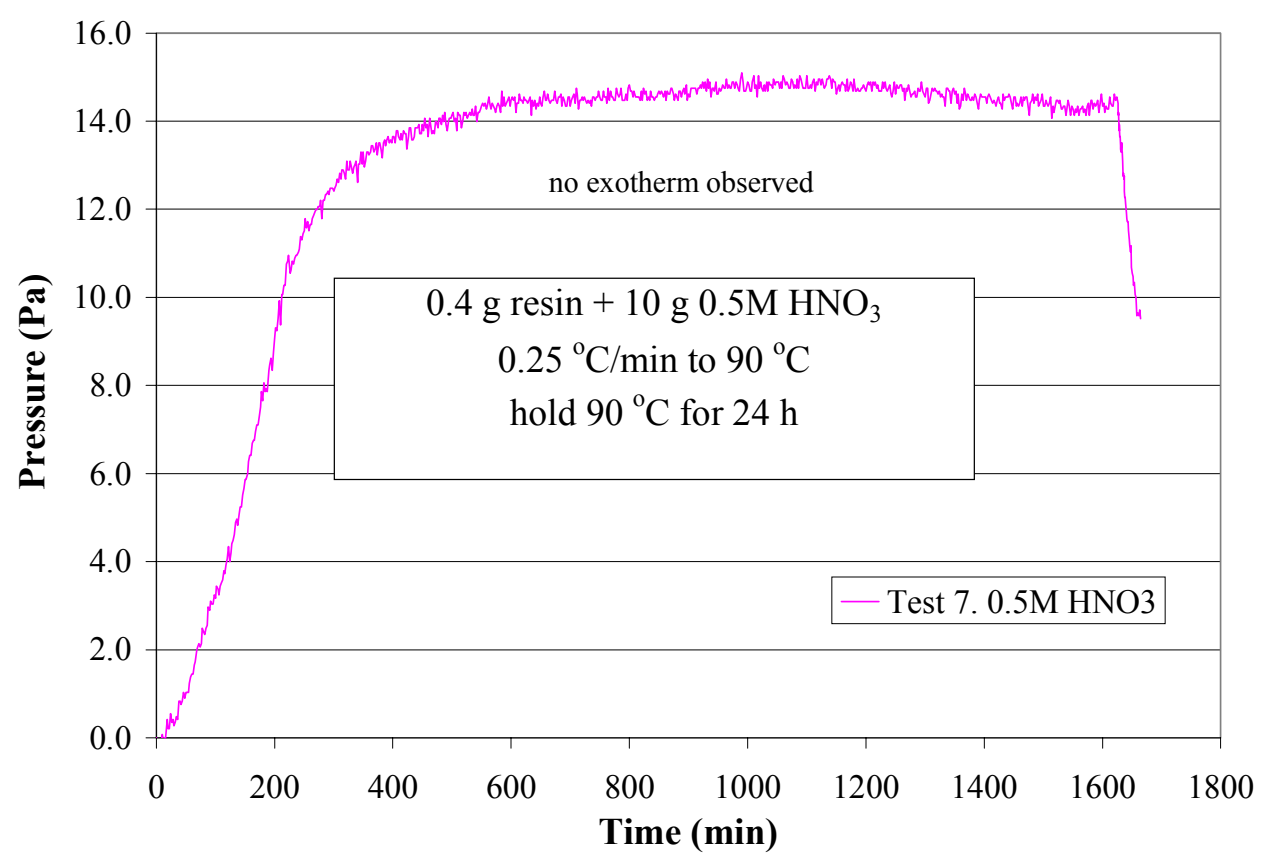


WSRC-TR-2000-00304, Rev. 0

SRT-RPP-2000-00005

Rev. 0

Figure 17. SuperLig ${ }^{\circledR} 644$ resin and 0.5 molar nitric Acid at 0 Pascal: Self-heating Vs. TemPerature

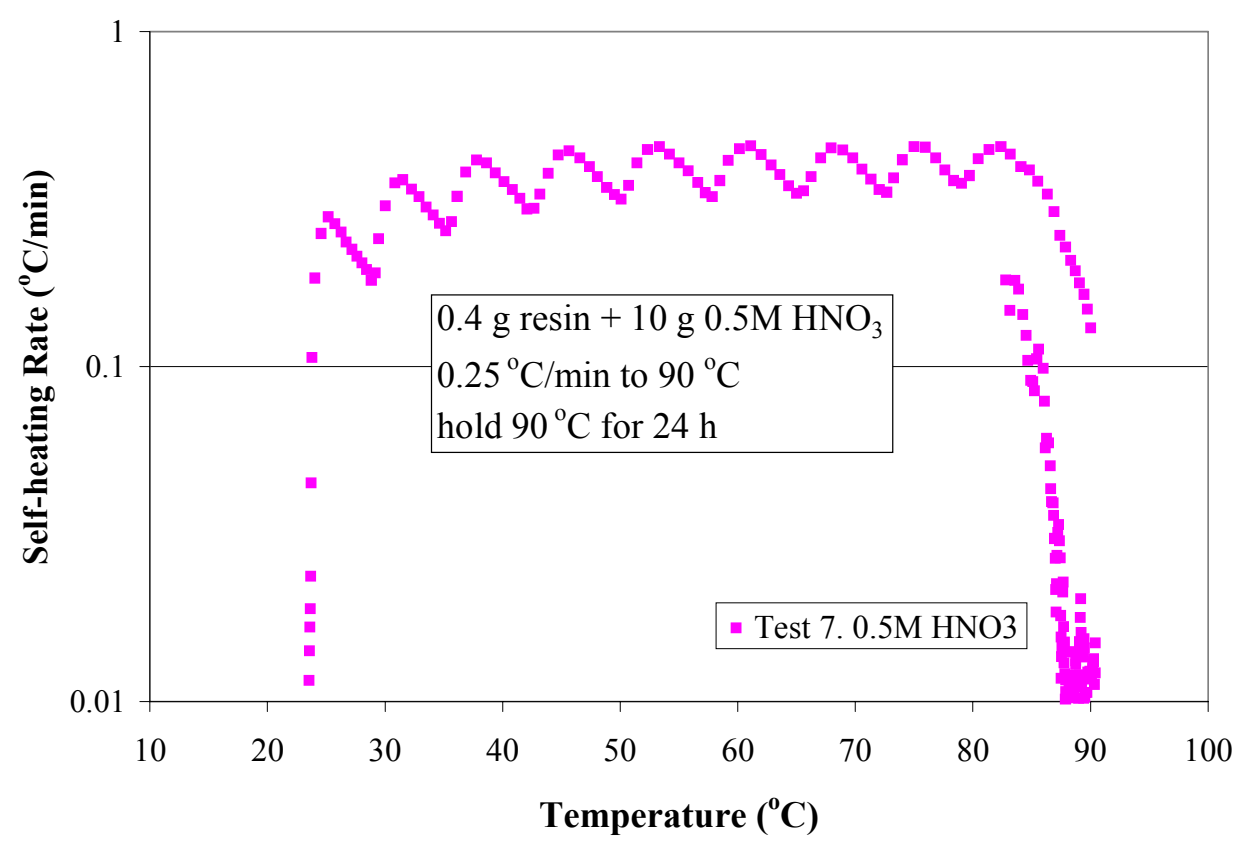

Figure 18. SuperLig ${ }^{\circledR} 644$ resin and 0.5 molar nitric Acid at 0 Pascal: Pressure Rate vs. Temperature

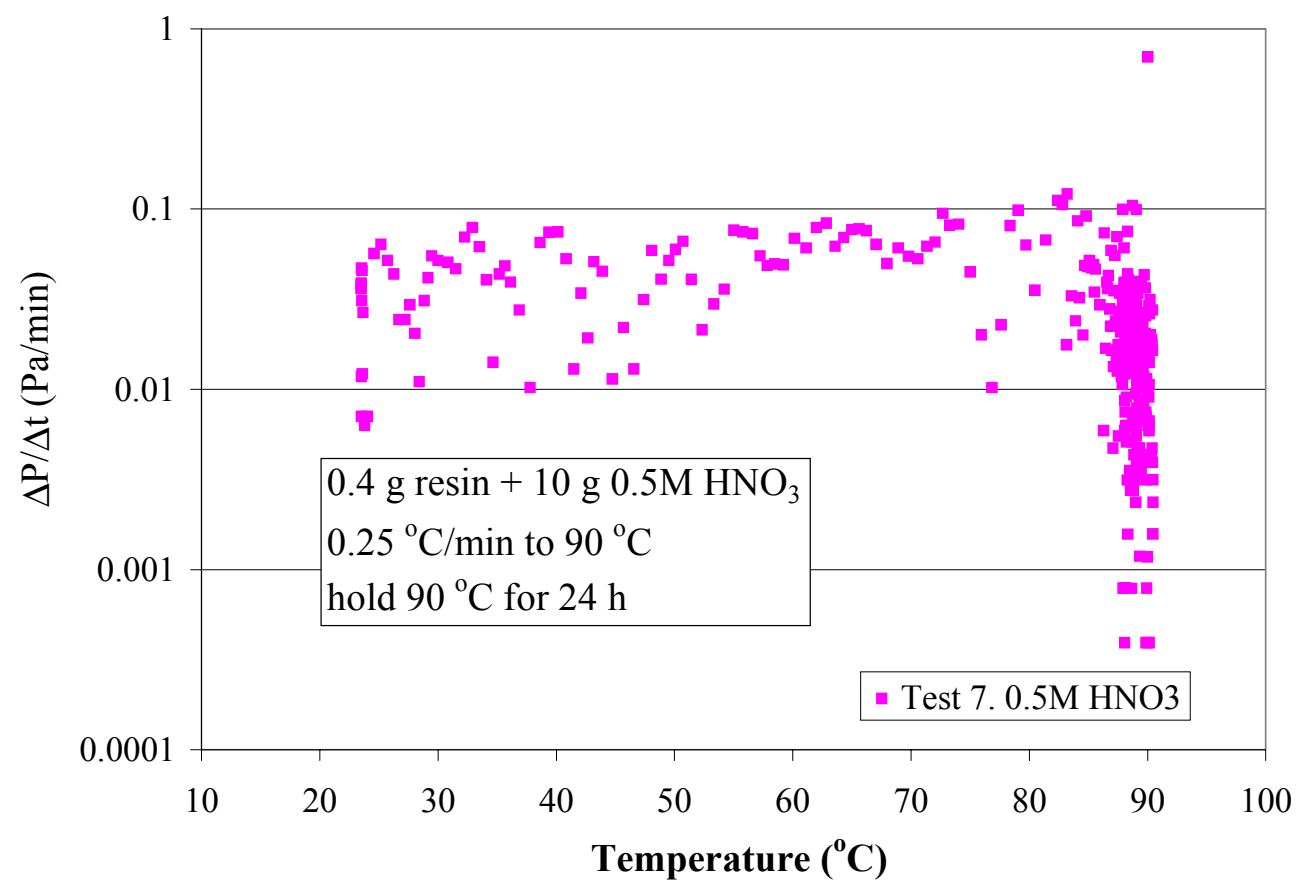


WSRC-TR-2000-00304, Rev. 0

SRT-RPP-2000-00005

Rev. 0

Figure 19. SuperLig ${ }^{\circledR} 644$ resin and 5 molar Nitric Acid

From Ambient T: Temperature vs. Time

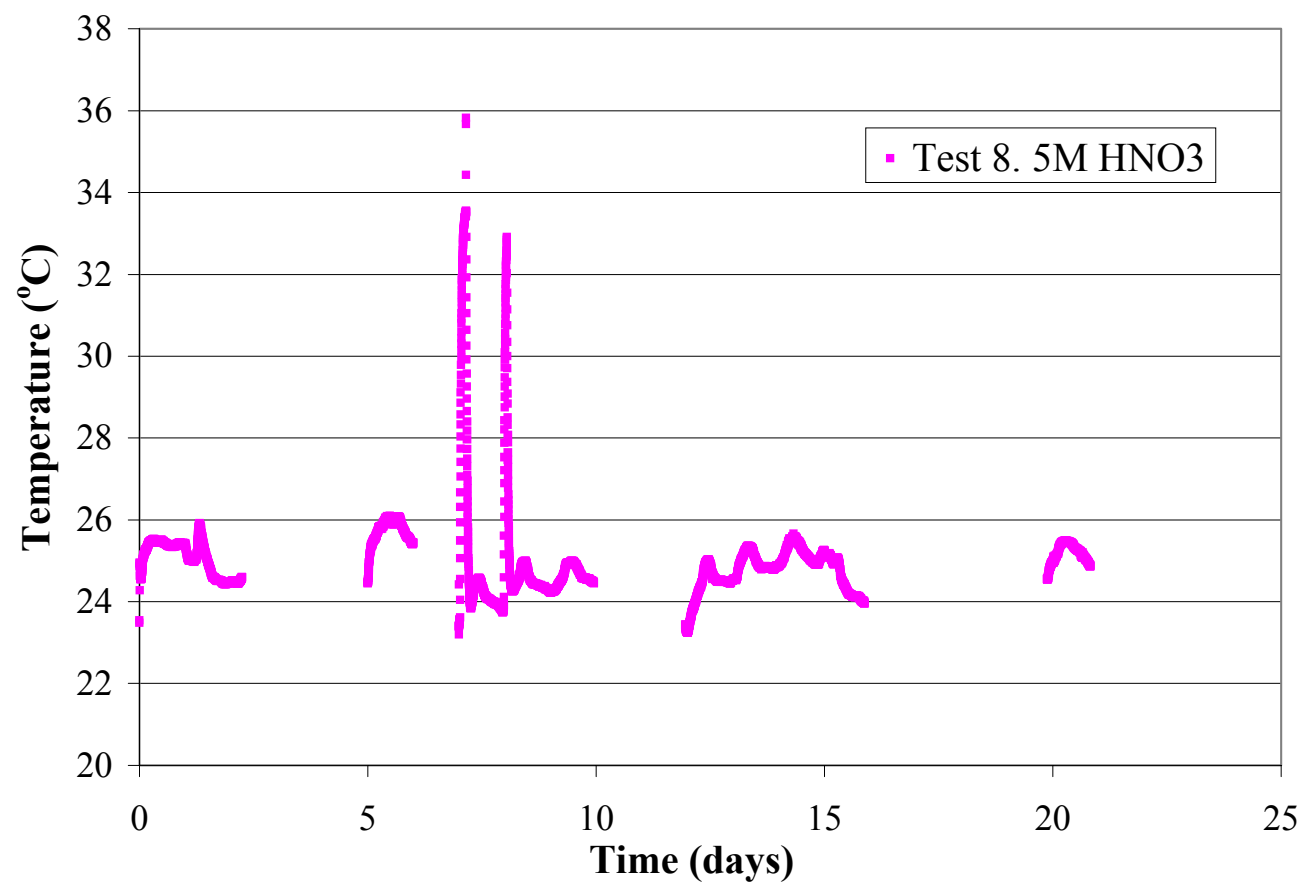

Figure 20. SuperLig ${ }^{\circledR} 644$ resin and 5 molar Nitric Acid FROM AMBIENT T: PRESSURE VS. TIME

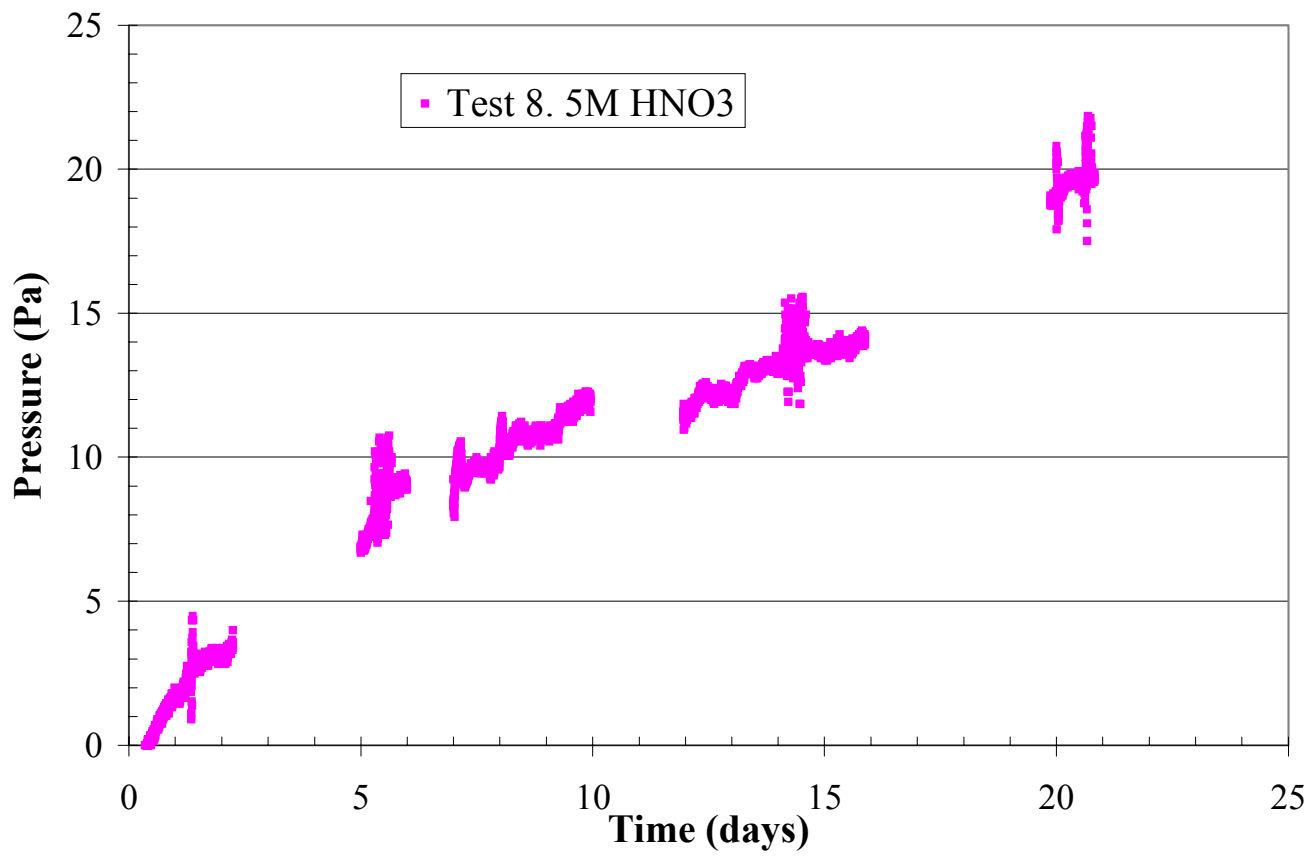


WSRC-TR-2000-00304, Rev. 0

SRT-RPP-2000-00005

Rev. 0

Figure 21. SuperLig ${ }^{\circledR} 644$ resin and 5 molar Nitric Acid FROM AMBIENT T: SELF-HEATING VS. TEMPERATURE

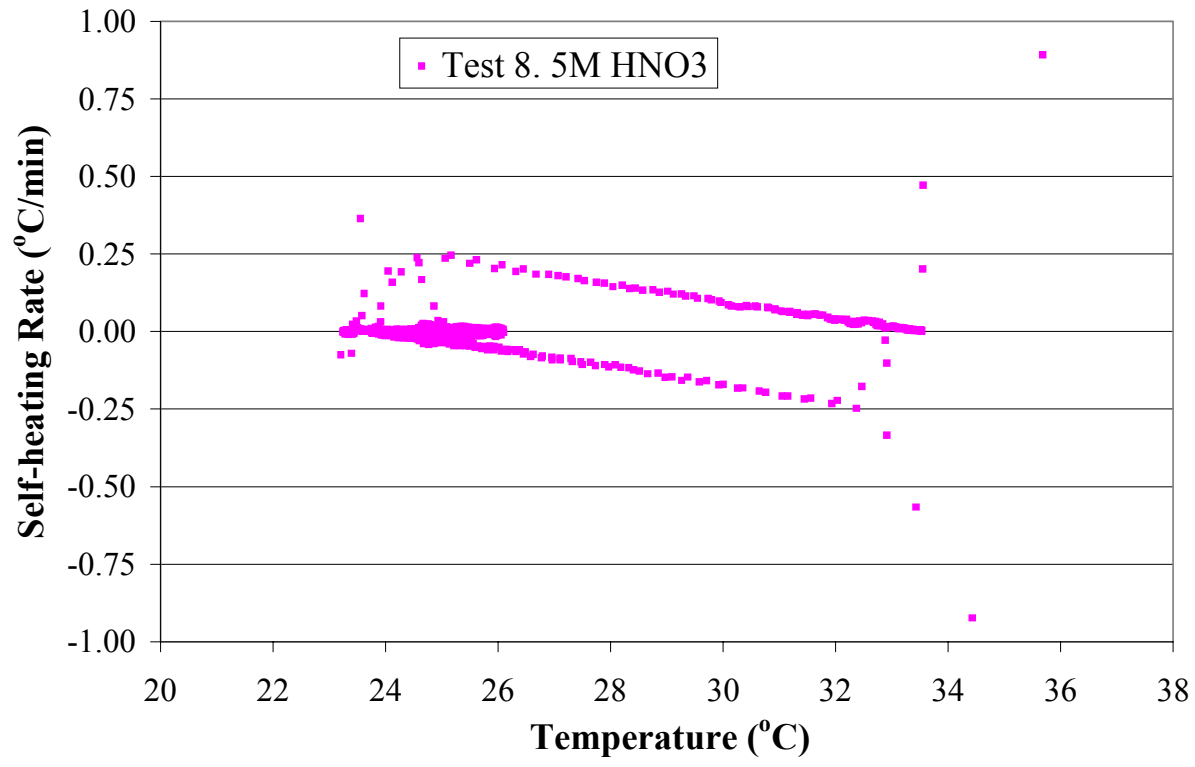

Figure 22. SuperLig ${ }^{\circledR} 644$ resin and 5 molar Nitric Acid FROM AMBIENT T: PRESSURE RATE VS. TEMPERATURE

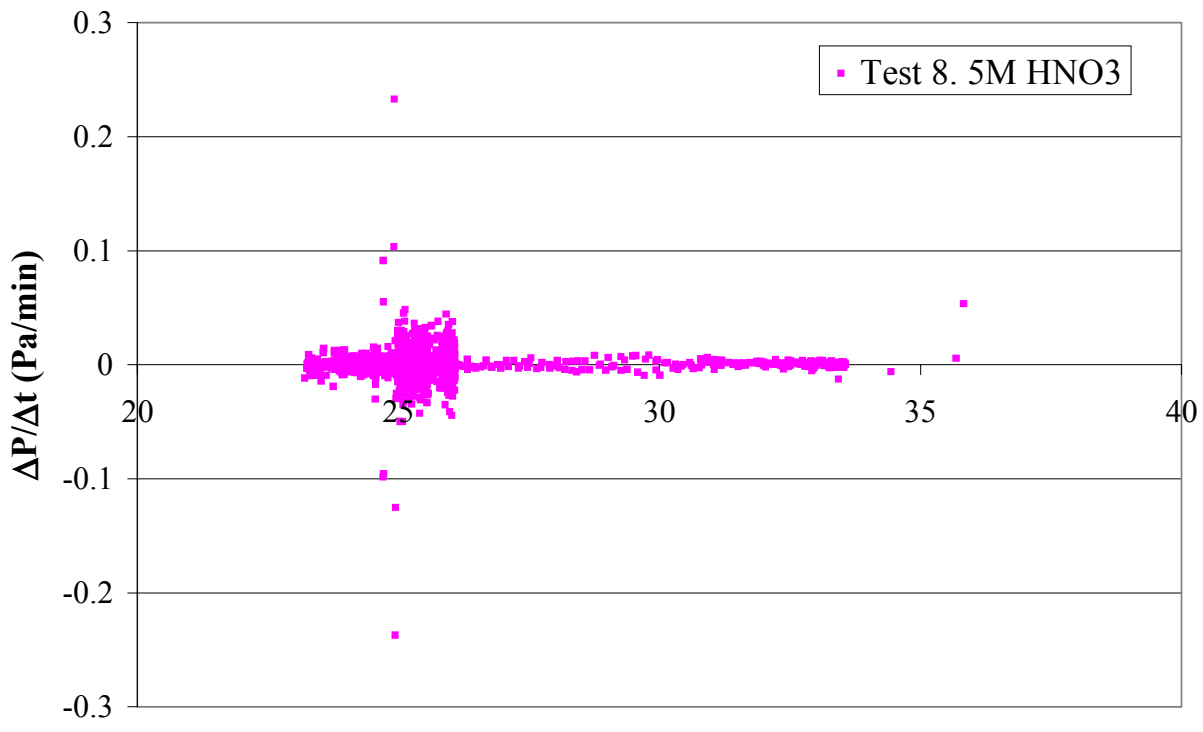

Temperature $\left({ }^{\circ} \mathrm{C}\right)$ 
WSRC-TR-2000-00304, Rev. 0

SRT-RPP-2000-00005

Rev. 0

Figure 23. Caustic Neutralization of "SuperLig ${ }^{\circledR} 644$ solution" At 0 PASCAL: Temperature Vs. Time

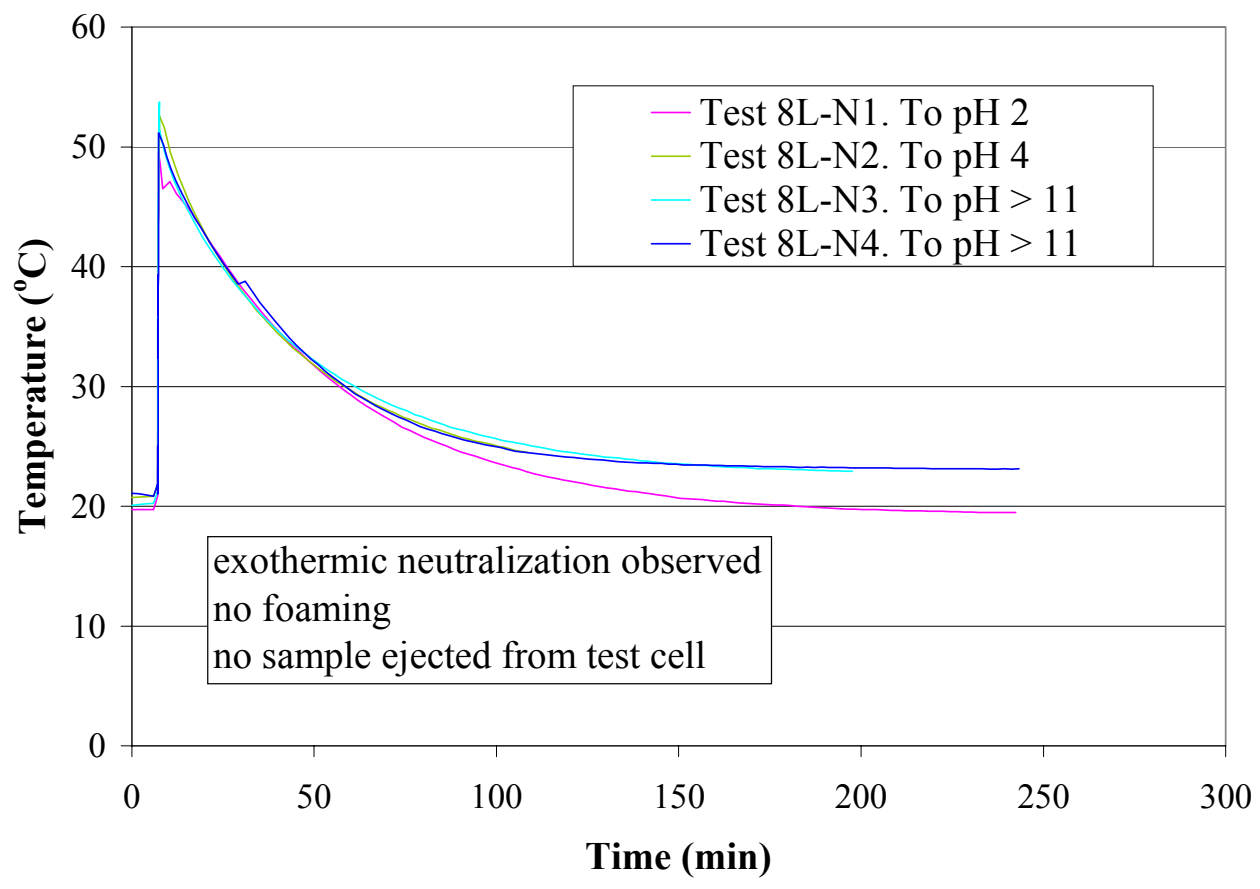

Figure 24. Caustic Neutralization of "SuperLig ${ }^{\circledR} 644$ solution" At 0 PASCAL: PRESSURE VS. TIME

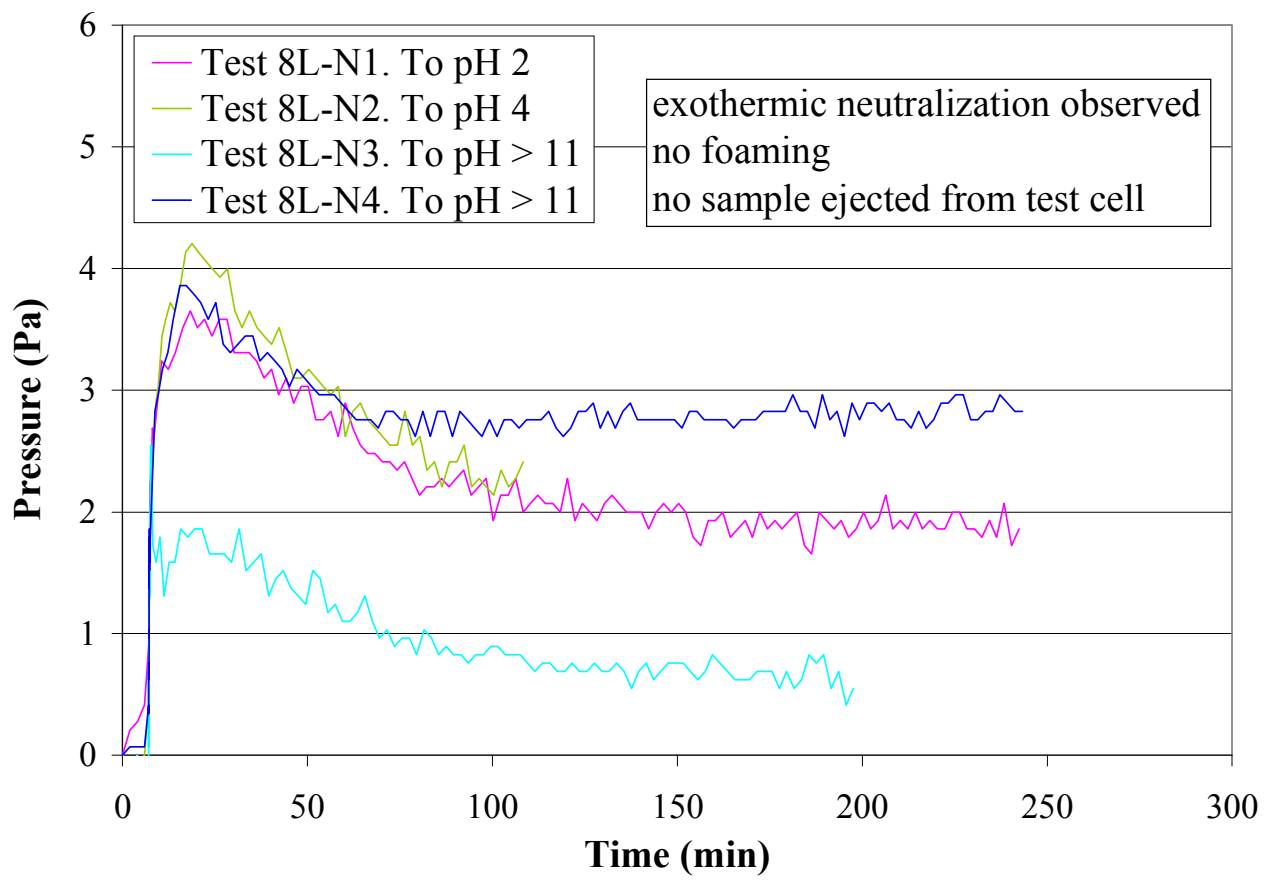


Figure 25. Caustic Neutralization of "SuperLig ${ }^{\circledR} 644$ solution" AT 0 PASCAL: SELF-HEATING Vs. TEMPERATURE

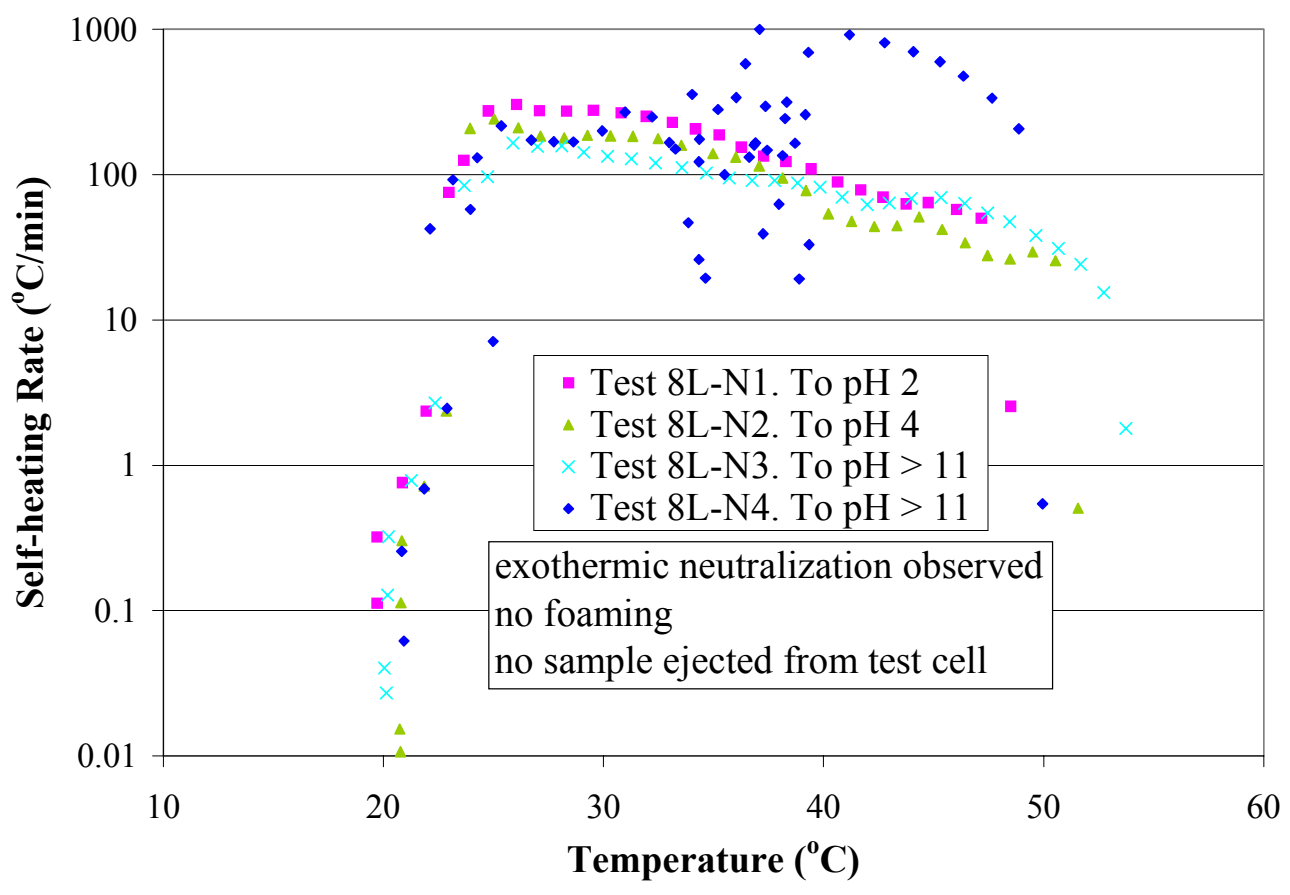

Figure 26. Caustic Neutralization of "SuperLig ${ }^{\circledR} 644$ solution" at 0 Pascal: Pressure Rate vs. Temperature

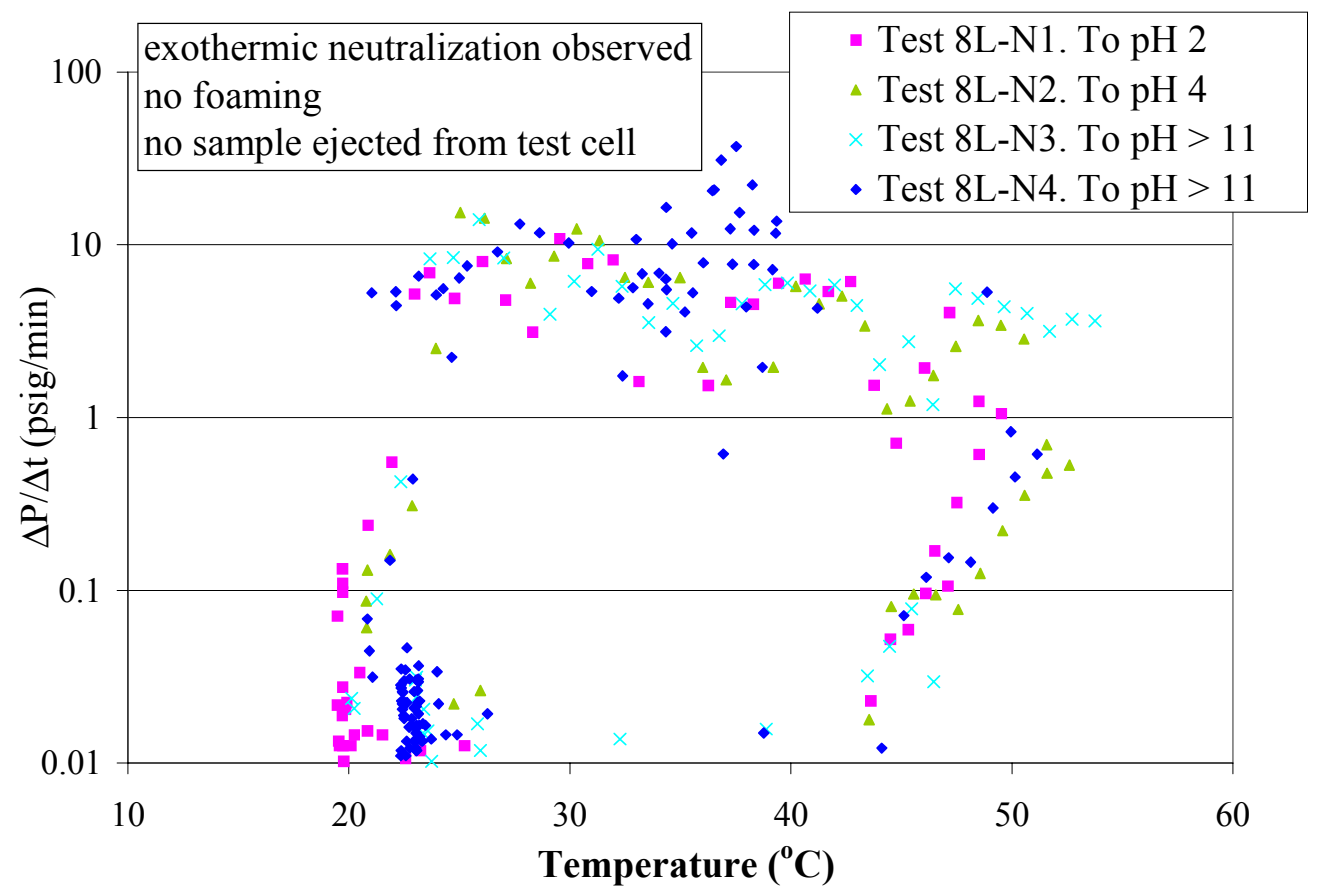


WSRC-TR-2000-00304, Rev. 0

SRT-RPP-2000-00005

Rev. 0

Figure 27. SuperLig ${ }^{\circledR} 644$ resin and Water

FROM AMBIENT T: TEMPERATURE VS. TIME

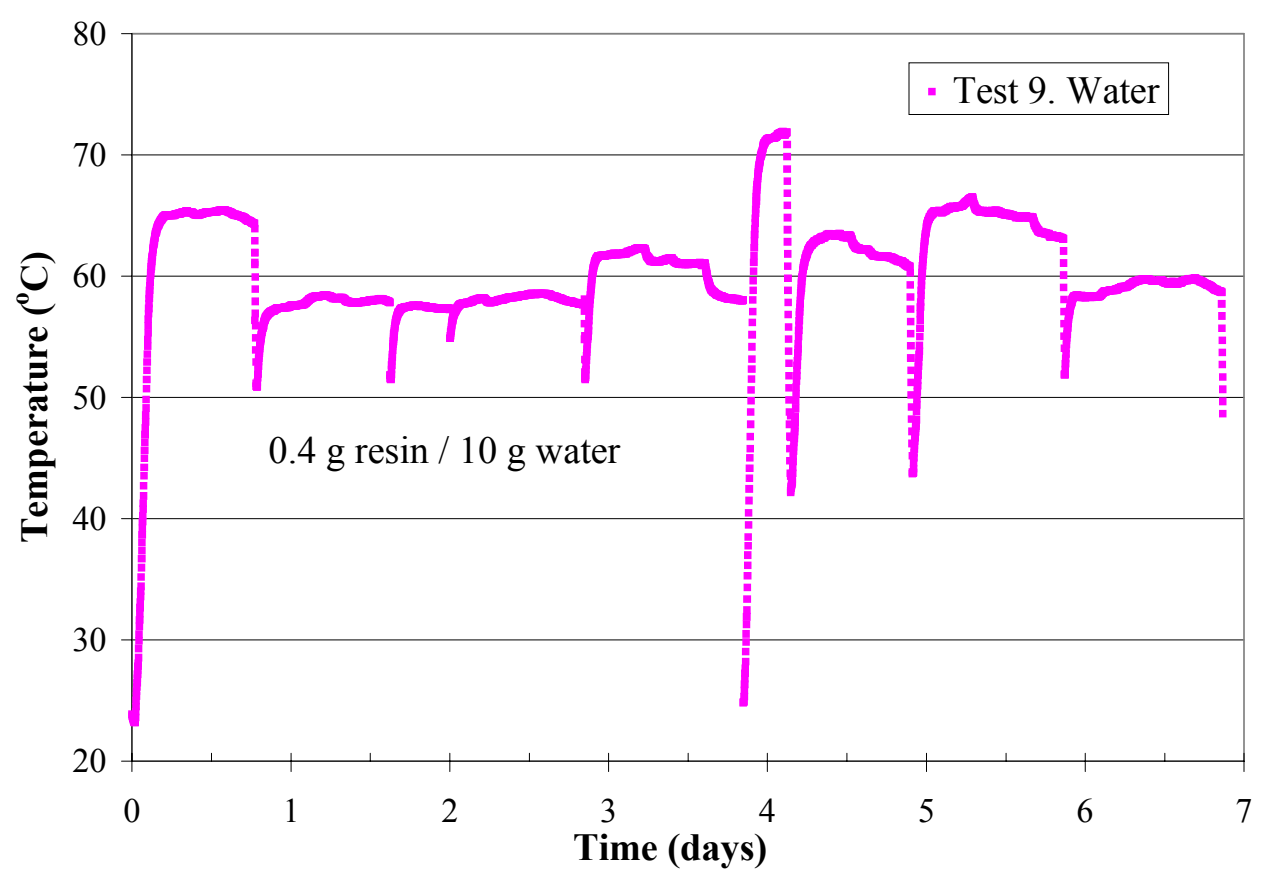

Figure 28. SuperLig ${ }^{\circledR} 644$ resin and Water FROM AMBIENT T:PRESSURE VS. TIME

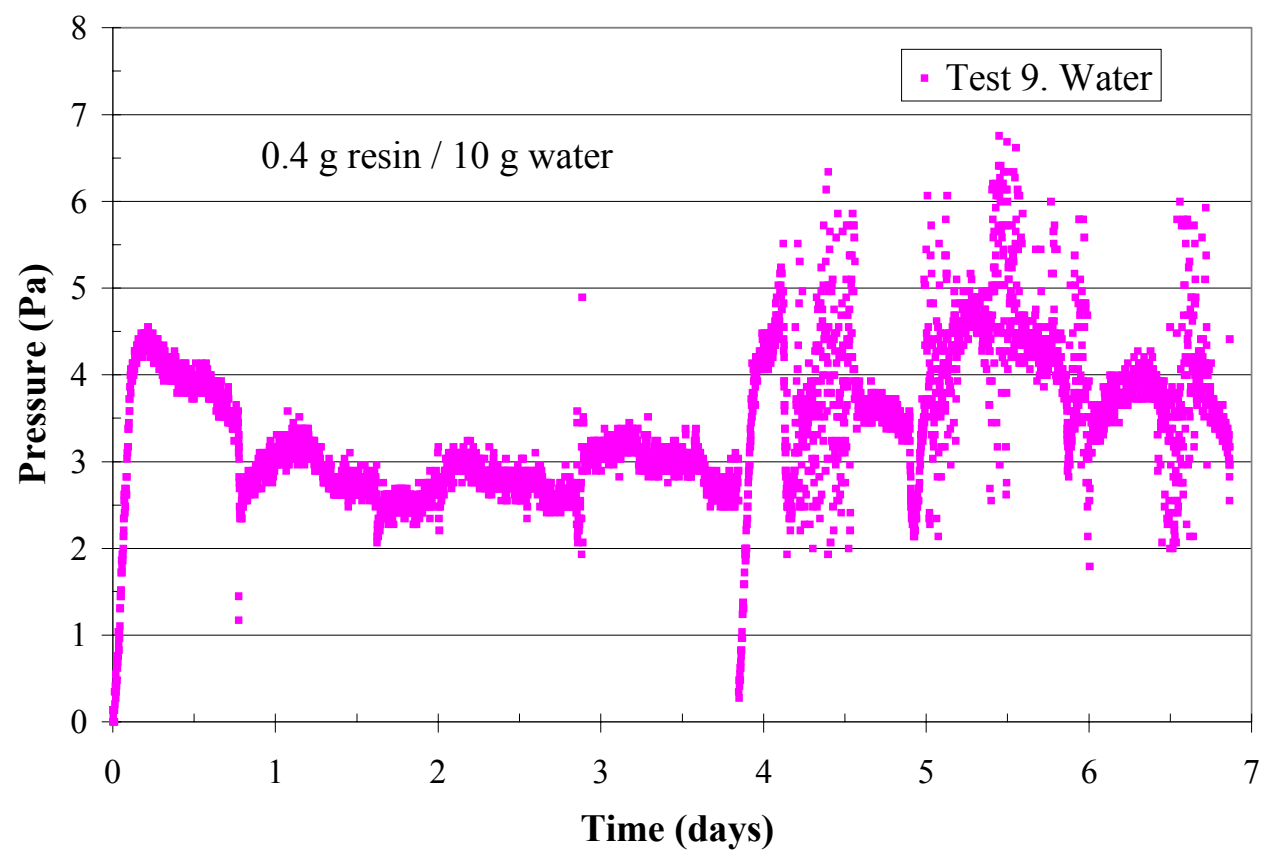


WSRC-TR-2000-00304, Rev. 0

SRT-RPP-2000-00005

Rev. 0

Figure 29. Caustic Neutralization of "SuperLig ${ }^{\circledR} 644$ solution" at 0 Pa: Self-heating vs. Temperature

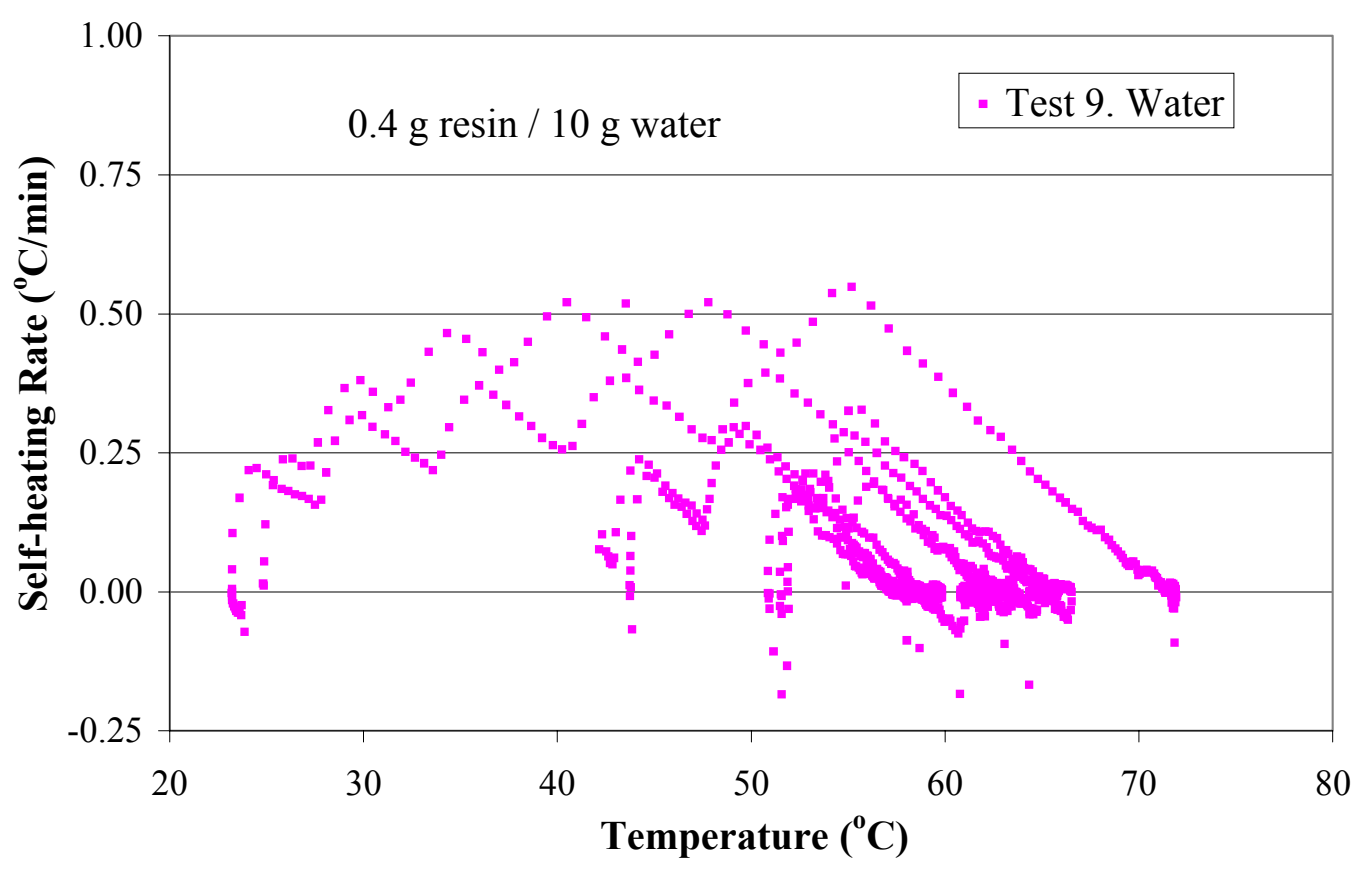

Figure 30. Caustic Neutralization of "SuperLig ${ }^{\circledR} 644$ solution" at 0 Pa: Pressure Rate vs. Temperature

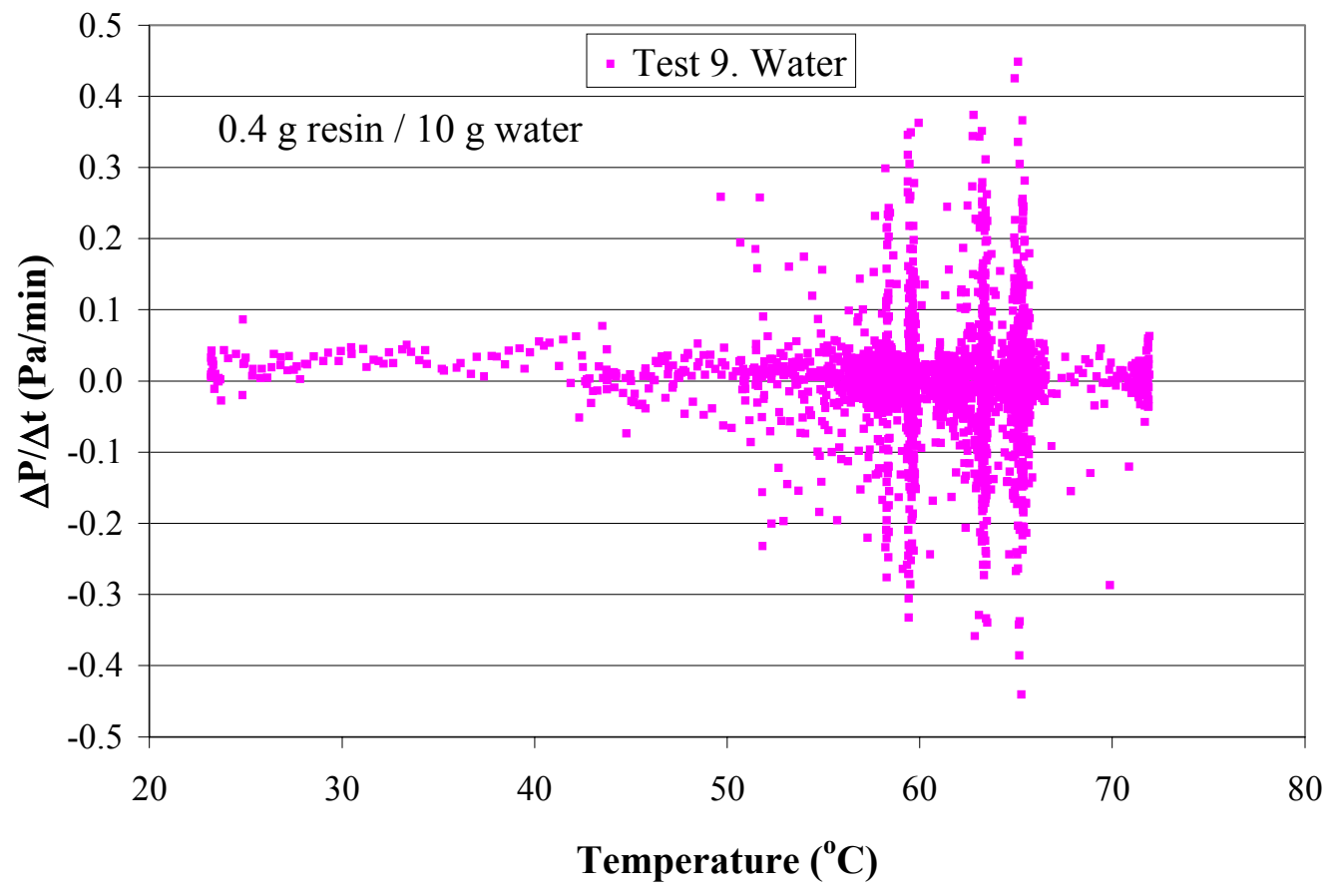


WSRC-TR-2000-00304, Rev. 0

SRT-RPP-2000-00005

Rev. 0

Figure 31. ICMS of the product from Test 8: "Partial" dissolution of SL644 in 5M nitric acid at $25{ }^{\circ} \mathrm{C}$ for 21 days

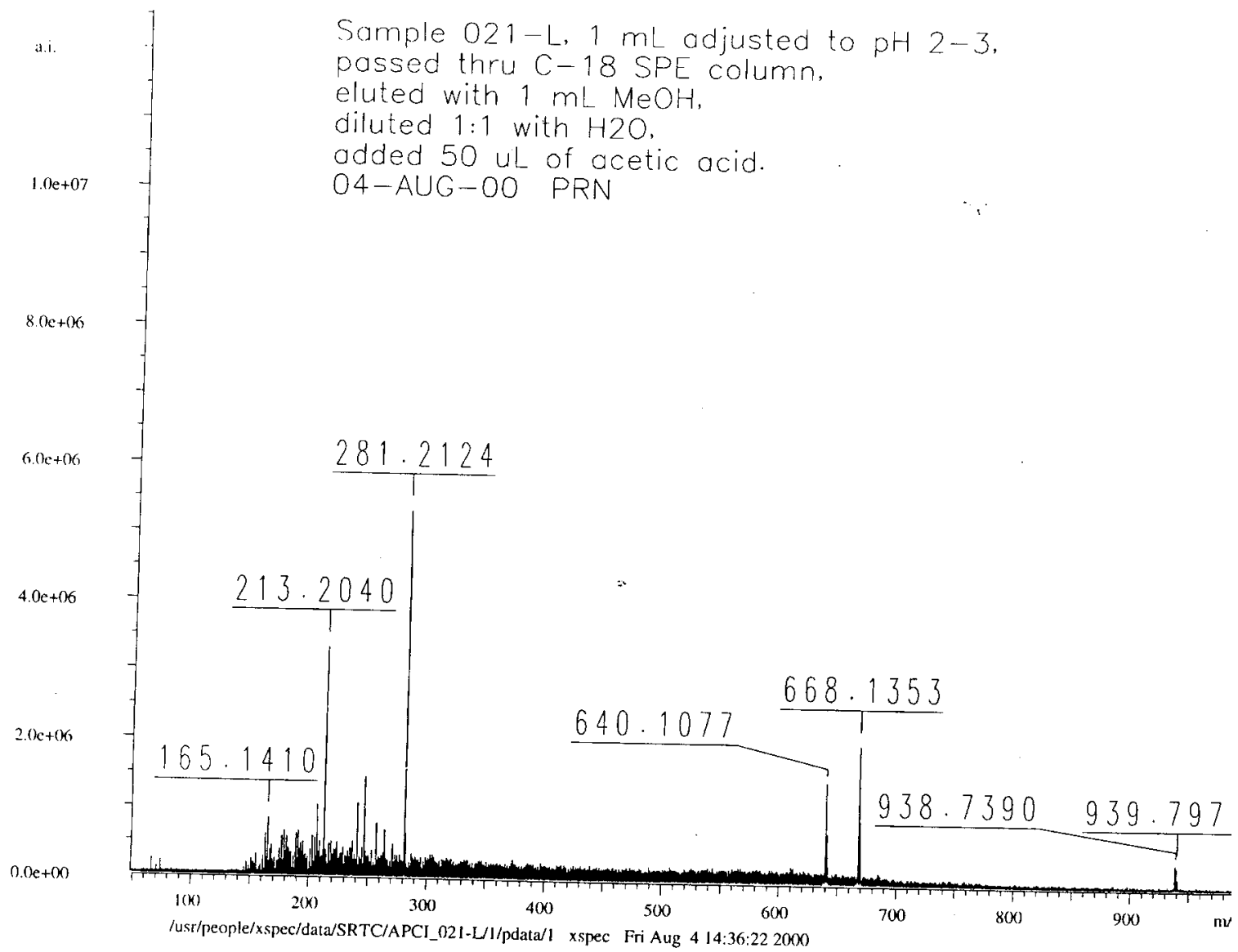


WSRC-TR-2000-00304, Rev. 0

SRT-RPP-2000-00005

Rev. 0

Figure 32. ICMS of the product from Test 8: "Complete" dissolution of SL644 in 5M nitric acid at $90{ }^{\circ} \mathrm{C}$ for 8 hours

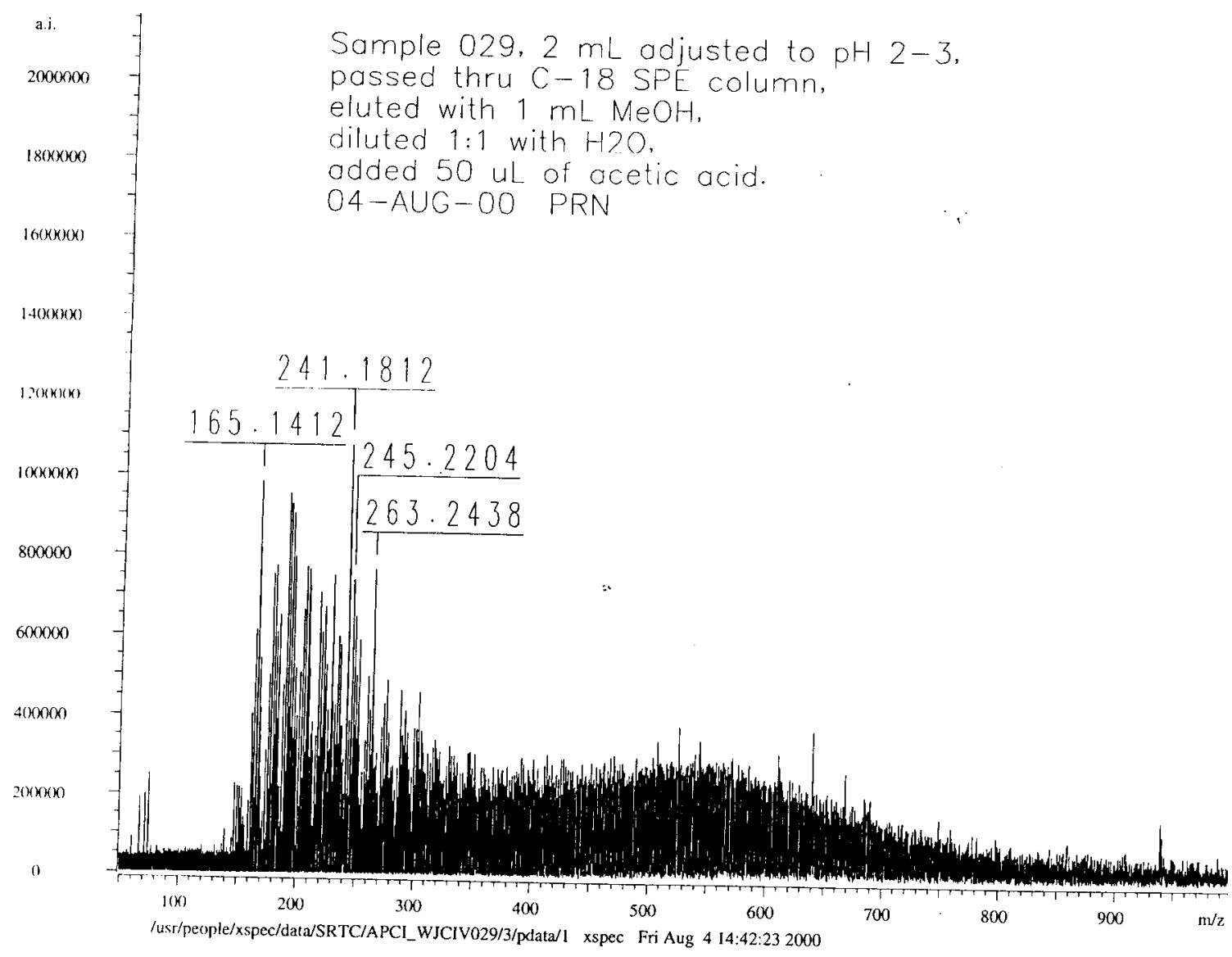


WSRC-TR-2000-00304, Rev. 0

SRT-RPP-2000-00005

Rev. 0

Figure 33. ICMS of the product from Test 9: Partial dissolution of SL644 in Distilled Water at $60{ }^{\circ} \mathrm{C}$ for 7 days

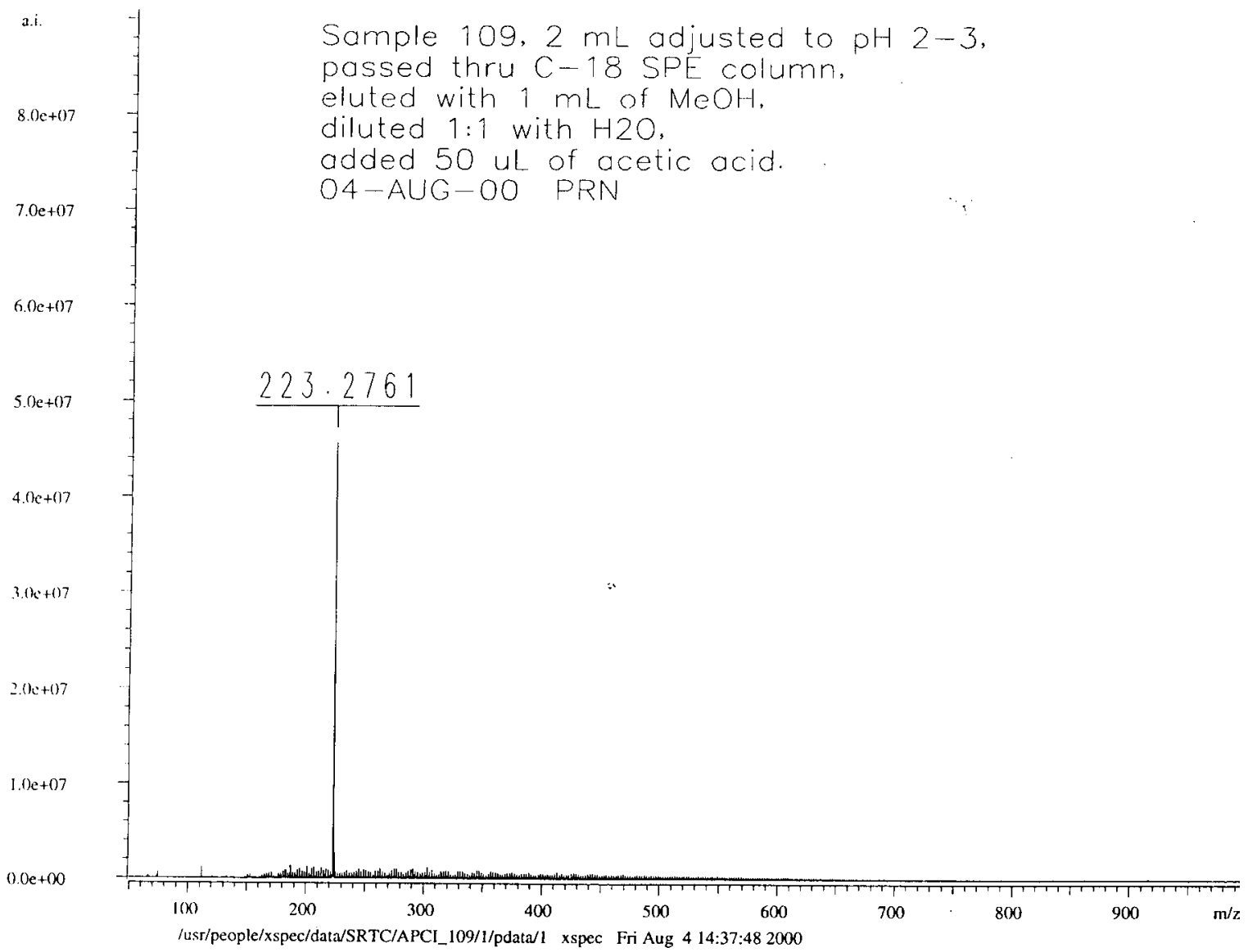


WSRC-TR-2000-00304, Rev. 0

SRT-RPP-2000-00005

Rev. 0

Figure 34. DSC of Test 7: Resin $+0.5 \mathrm{M} \mathrm{HNO}_{3}$ at $90{ }^{\circ} \mathrm{C}$ for 24 hours $\rightarrow$ Liquid Residue
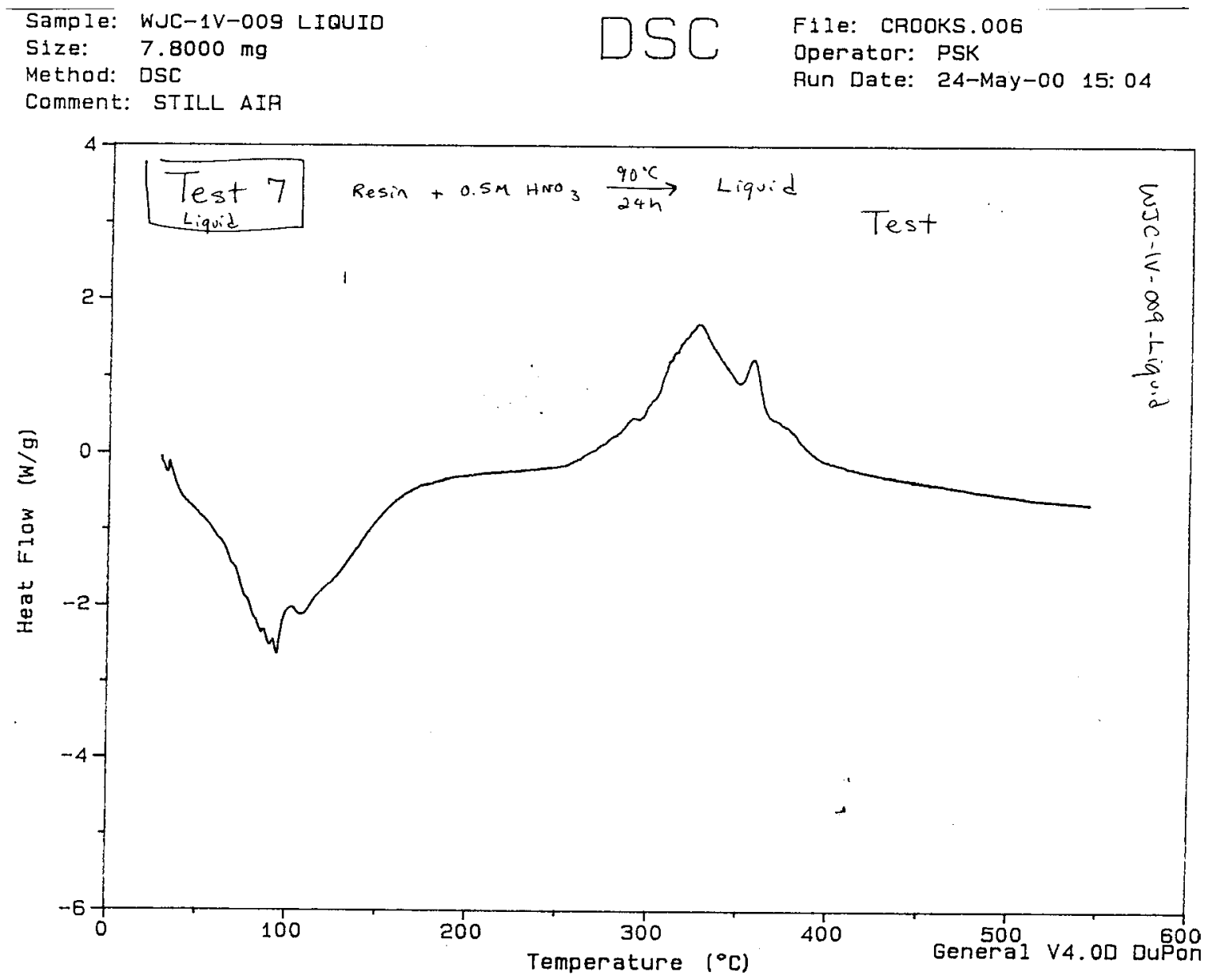
WSRC-TR-2000-00304, Rev. 0

SRT-RPP-2000-00005

Rev. 0

Figure 35. DSC of Test 7: Resin $+0.5 \mathrm{M} \mathrm{HNO}_{3}$ at $90{ }^{\circ} \mathrm{C}$ for 24 hours $\rightarrow$ Solid Residue

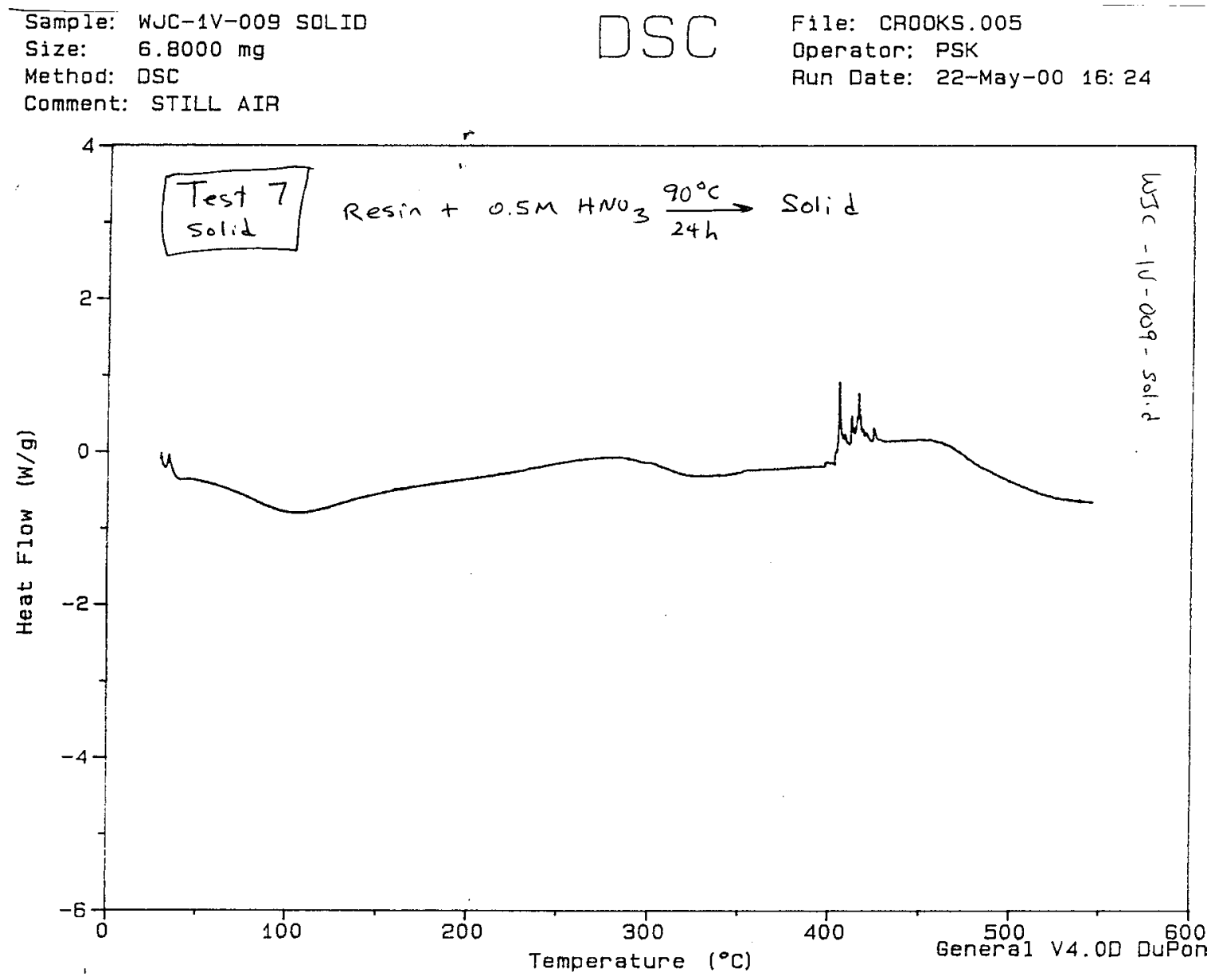


WSRC-TR-2000-00304, Rev. 0

SRT-RPP-2000-00005

Rev. 0

Figure 36. DSC of Test 8: Resin $+5 \mathrm{M} \mathrm{HNO}_{3}$ at ambient temperature for 21 days $\rightarrow$ Liquid Residue

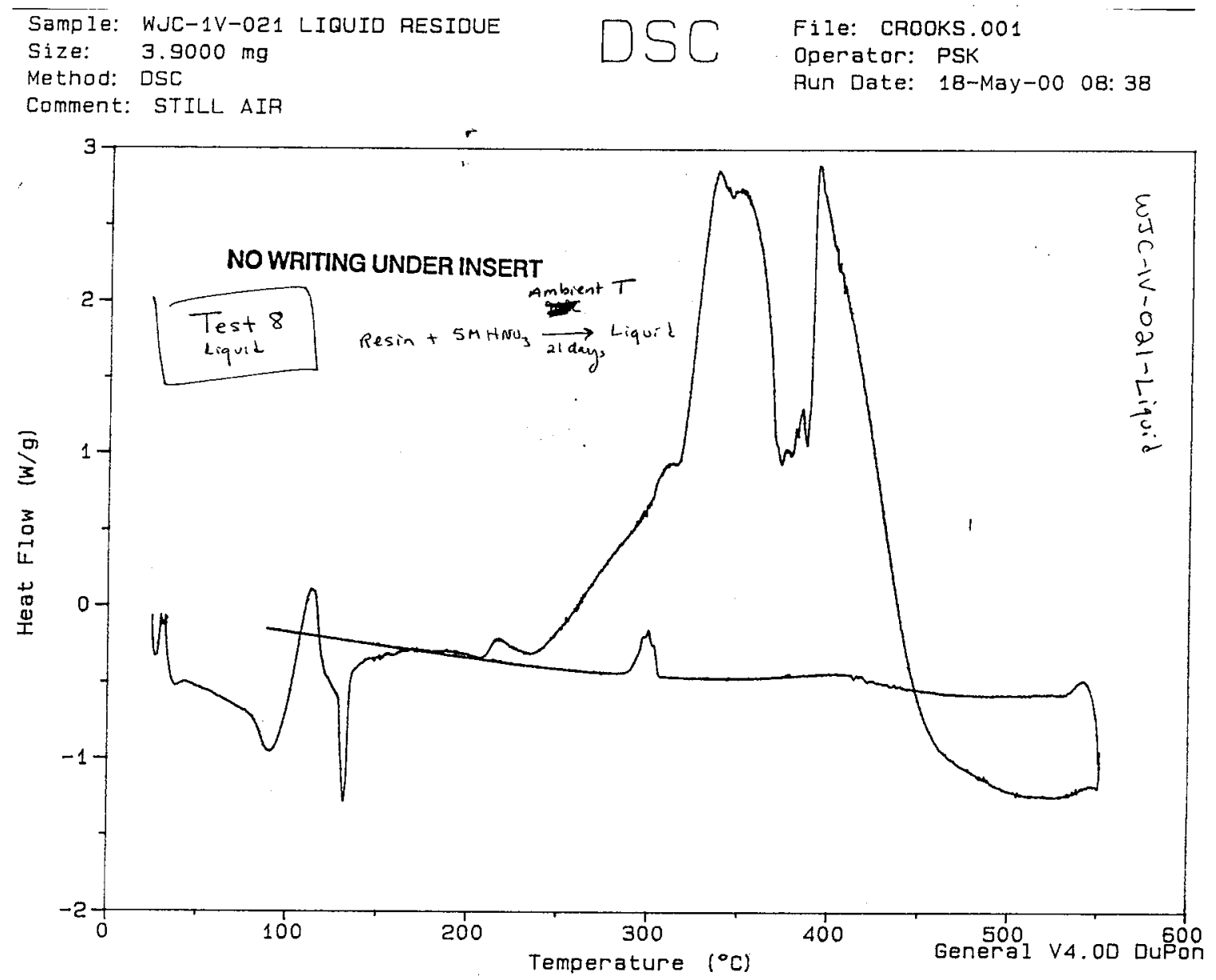


WSRC-TR-2000-00304, Rev. 0

SRT-RPP-2000-00005

Rev. 0

Figure 37. DSC of Test 8: Resin $+5 \mathrm{M} \mathrm{HNO}_{3}$ at ambient temperature for 21 days $\rightarrow$ Solid Residue

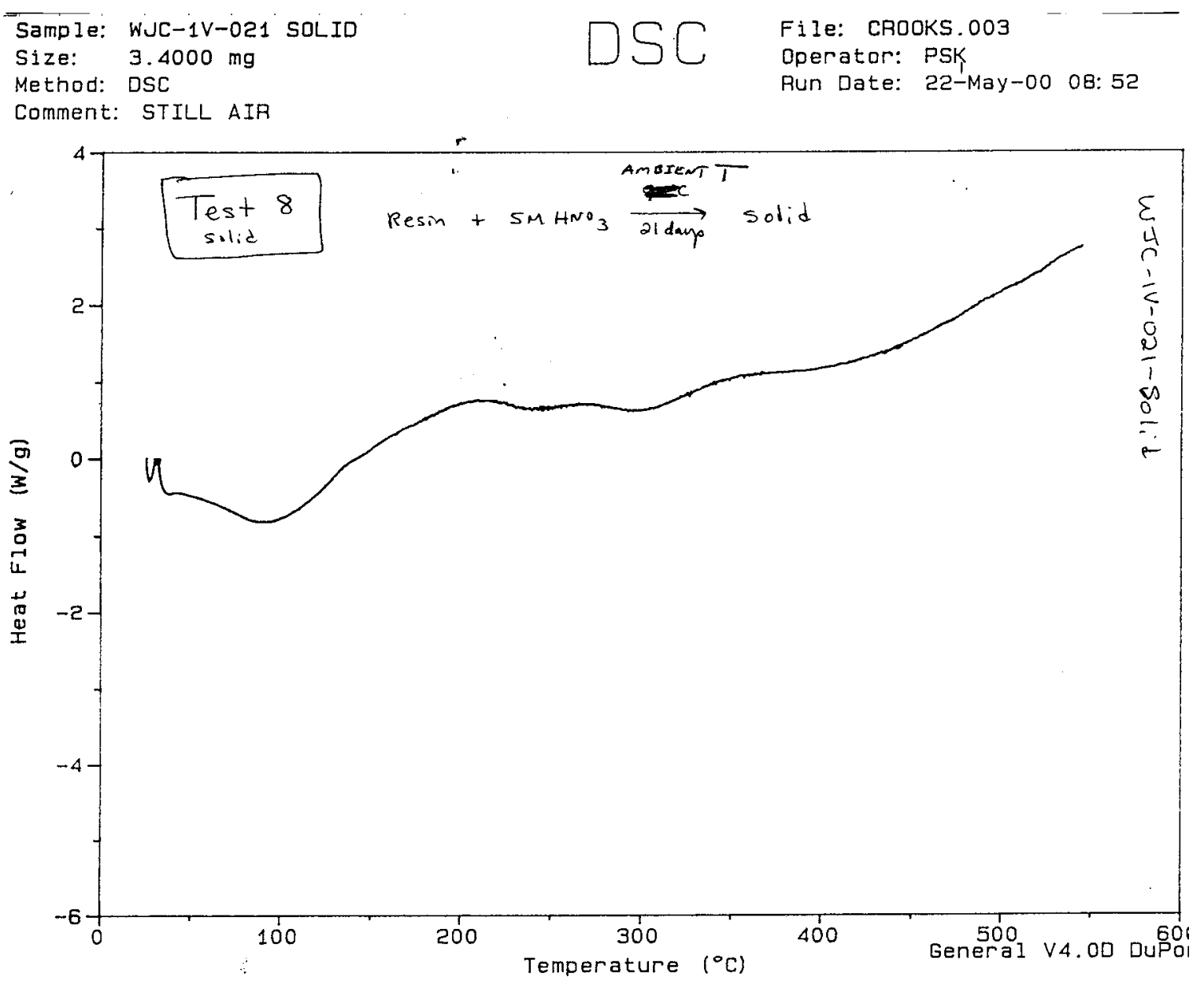


WSRC-TR-2000-00304, Rev. 0

SRT-RPP-2000-00005

Rev. 0

Figure 38. DSC of Test 9: Resin $+\mathrm{H}_{2} \mathrm{O}$ at $60{ }^{\circ} \mathrm{C}$ for 7 days $\rightarrow$ Liquid Residue

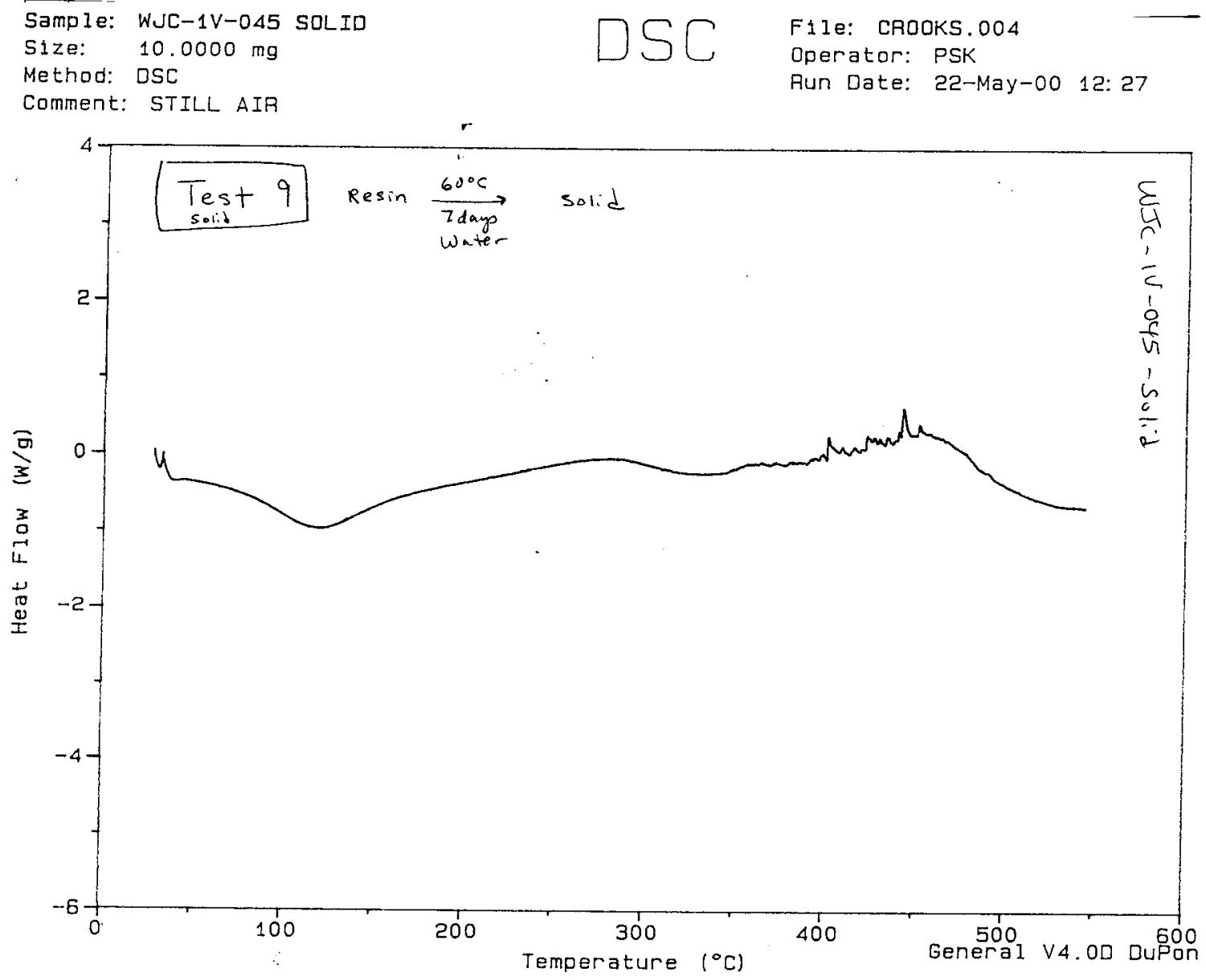


WSRC-TR-2000-00304, Rev. 0

SRT-RPP-2000-00005

Rev. 0

Figure 39. DSC of Test 9: Resin $+\mathrm{H}_{2} \mathrm{O}$ at $60{ }^{\circ} \mathrm{C}$ for 7 days $\rightarrow$ Solid Residue

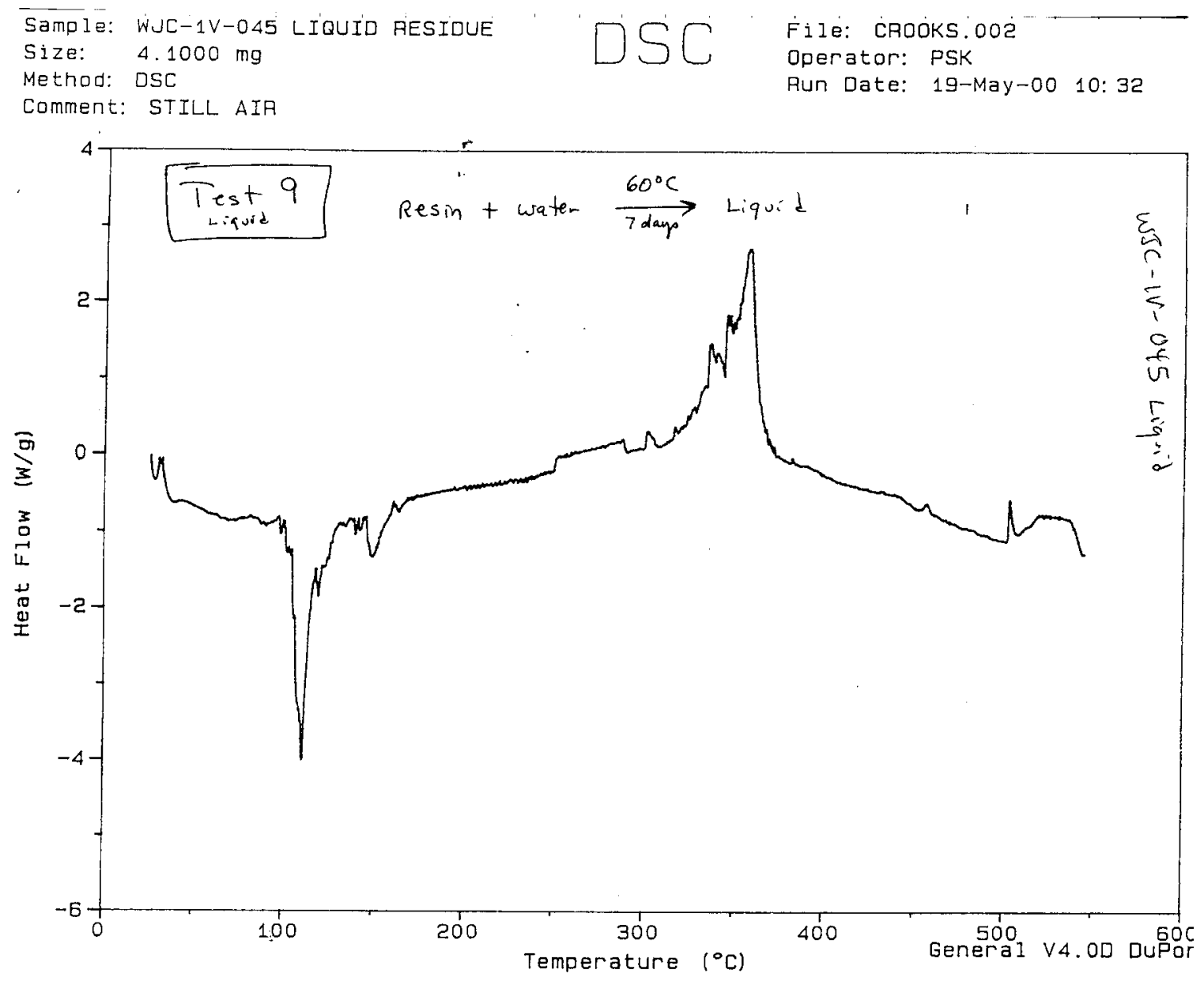




\section{REFERENCES}

\footnotetext{
${ }^{1}$ W.J. Crooks III, C. A. Nash, D. J. McCabe, H. H. Saito, "Studies of Ion Exchange Resin Integrity under Flowsheet Extremes: Part II", a Task Technical and Quality Assurance Plan for the present work, BNF003-98-0225, Rev. 0, April 17, 2000

${ }^{2}$ W.J. Crooks III, D. J. McCabe, "Evaluating Effects from Contacting SuperLig ${ }^{\circledR} 644$ Resin with Sodium Permanganate”, WSRC-TR-2001-00235; SRT-RPP-2001-00105, rev. 0, March 2002.

${ }^{3}$ H. H. Saito, W.J. Crooks III, D. J. McCabe, C. A. Nash, "SuperLig 644 Ion Exchange Resin Stability in Nitric Acid at Elevated Temperatures", WSRC-TR-2000-00411; SRT-RPP-2000-00027, rev. 0, February
} 2001.

${ }^{4}$ H.T. Fullam, G. Jansen, Jr. and W.J. Van Slyke, Thermal Instabilities in Anion Exchange Processing, Conference on Ion Exchange in the Process Industry. Society of Chemical Industry, London, July 16-18, 1969.

${ }^{5}$ F.W. Miles, "Ion-Exchange-Resin Failures in Processing Actinides, Nuclear Safety, 1968, 9, 394-406.

${ }^{6}$ D.C. Bartholomew, E.J. Kosiancic, B.J. McMurray, D.D. Wodrich and W.M. Harty, Explosion of Ion Exchange Resin in Americium Recovery Service, Hanford Plant, August 30, 1976. Report, Atlantic Richfield Hanford Co., Richland, WA, 1976.

${ }^{7}$ P.G. Rhoades, P.E. Ruhter, M.W. Shupe, R.E. Gerton, Investigations of the Chemical Explosion of an Ion Exchange Resin Column and Resulting Contamination of Personnel in the 242-Z Building, August 30, 1976. Report, Energy Research and Development Agency, Richland Operations Office, Richland, WA, 1976.

${ }^{8}$ Bruening, R. L., "Chemical Stability of Ion Exchange Materials", Report to BNFL task work under subcontract \#TWSC99-109, Task 5, IBC Advanced Technologies, February 4, 2000.

${ }^{9}$ National Fire Protection Association (NFPA), "Fire Protection for Laboratories Using Chemicals", NFPA 45.

${ }^{10}$ U.S. Department of Energy, "DOE Explosives Safety Manual," DOE M 440.1-1, September 30, 1995. 